\title{
IN WITH THE OLD AND OUT WITH THE NEW
}

adaptive re-use of our dying school

By

\section{Ajantha Kumarasingam}

A thesis submitted to the Faculty of Graduate and Postdoctoral Affairs in partial fulfillment of the requirements for the degree of

\author{
Master of Architecture \\ M. Arch. Professional \\ Carleton University \\ Ottawa, Ontario
}

(C) 2014 


\section{ACKNOWLEDGEMENTS}

I would like to first and foremost thank my

supervisor Mariana Esponda, for her dedication and

support throughout my thesis. Thank you to the

individuals from Fairbank community who took the time to

participate in the interviews and surveys and sharing their

experiences and insights. I would like to thank my family

and friends for their love and encouragement. Finally,

special thanks to Suhujitha Parasuraman for all the

endless hours of editing over the last twenty years of my

education. 


\section{ABSTRACT}

Architecture and communities together create a 'sense of place'. Communities transform over time due to the economic and social needs. Consequently, architecture should be transforming as well in order to respond to surrounding context, however it is not.

Among many structures, schools are important to create a sense of community for neighborhoods. Schools today are under enormous pressure to maintain educational excellence meanwhile facing continuous budget cuts. Thus, many schools across the country are facing endangerment. These sites can be considered desirable for future development; however, many are simply abandoned or demolished due to time and money.

Historic schools like any other form of architecture have layers of history, values and memories. The history behind a structure consists of forms of transformation based on alternation and recreation that continue the life of a building. This thesis seeks to explore the relationship between architecture and communities through adaptive reuse and participatory design in order to enrich the experience and meaning of the building. Determining how existing schools can be adaptively reused in neighborhoods and continue to act as community hubs for local activities and interaction between people. As a hypothesis, this thesis transforms a school in the City of Toronto into a community center. Architectural palimpsest and transformation is a central design concept that drives this design to preserve the past by integrating the old history with a new purpose. 


\section{TABLE OF CONTENTS}

ACKNOWLEGDE

ABSTRACT

LIST OF FIGURES

V

PROLOGUE

vii

INTRODUCTION

THE PROBLEM 3

School Closures as a Problem

Current Solutions to School Closures

Precedence

ADAPTIVE REUSE

8

BACKGROUND INFORMATION 12

Schools as Building Typology

Perception of Old Schools

LEGISLATIVE POLICIES

15

Adaptive Reuse

Schools
NEIGHBORHOOD ANALYSIS

Context

School Closure in the Community

Neighborhood Evolution

Demographic Studies

SITE ANALYSIS

Site Context

Building History

Character Defining Elements

CLIENT REQUIREMENTS

40

DESIGN CONCEPT

Transformation \& Palimpsest

Participatory Design

DESIGN PROPOSAL

Intentions

Exterior

Interior

CONCLUSION

EPILOGUE

REFERENCE

\section{APPENDICES}




\section{LIST OF FIGURES}

Figure 1: School Closures Statistics

Figure 2: Artscape Youngplace Centre

Figure 3: Goodes Hall, Queen's University 10

Figure 4: Toronto District School Board and 19 the Toronto Land Corporation Disposition Framework

Figure 5: Geographical Location

Figure 6: Landuse Map

Figure 7: Map of Schools in the Area

Figure 8: Fairbank Map in 1878

Figure 9: Fairbank Evolution Timeline

Figure 10: Demographics Statistic

Figure 11: Demographics Statistic

Figure 12: Demographics Statistic

Figure 13: Briar Hill Junior Public School Area Map
Figure 14: Briar Hill Junior Public School

Evolution Timeline

Figure 15: Character Defining Elements

Figure 16: Bubble Diagram for Program Spaces 41

Figure 17: Neues Museum Exterior 43

Figure 18: Neues Museum Interior

Figure 19: Hedmark County Museum Interior 44

Figure 20: Hedmark County Museum Details 44

Figure 21: Castelvecchio Exterior 45

Figure 22: Castelvecchio Details 45

Figure 23: Kolumba Art Museum Exterior 46

Figure 24: Kolumba Art Museum Exterior 46

Figure 25: Design Sketches $\quad 59$

Figure 25: Proposed Site Plan 61

Figure 26: Proposed Basement Floor Plan 62

Figure 27: Proposed Ground Floor Plan 63

Figure 28: Proposed Second Floor Plan $\quad 64$ 
Figure 29: Perforated Brick Wall Detail

Figure 30: Proposed Exterior Elevations

\& Rendering

Figure 31: Proposed Section \& Interior

Renderings

Figure 32: Conceptual Site Plan
68

70

75 


\section{PROLOGUE}

As a child, there are so many memories of our childhood associated with our school. The hours in class, the breaks where you get to spend time with your friends at the playground and fields, to the after school adventures walking home. These are memories children remember. Like many schools, after hours schools serve as community spaces that provide parents and residents to come together and allow themselves and their children to interact with one another. These schools become more than just an educational facility, but a community hub for interaction, communication and togetherness. Losing your local school is like losing the heart of the community that provides liveliness to your neighborhood.
The Fairbank community was not chosen randomly for this thesis. It was chosen based on the media attention received because of the passion and dedication the residents of this community had for their beloved school. This site had strong history and value to the community, thus it was important to the residents to preserve the school. The initial intention of this thesis in the beginning of September 2013 was to provide alternative solution for this school through participatory design. The city official and residents have been strategizing alternative solutions to save the school. However, an abrupt decision was made and the school was demolished in early December by the owner. This was an unexpected turn of events for the community. Therefore, this thesis is a hypothetical adaptive reuse 
project based on the assumption that only a portion of the

building was demolished and the remainder of the

building was preserved on the site. 


\section{INTRODUCTION}

Schools are places of learning; they are vital anchors that act as community hubs for local activities. Among many structures, schools are important to create a sense of community for neighborhoods. These structures are created with a great deal of detail and craftsmanship. Schools today are under enormous pressure to maintain educational excellence meanwhile faced with many problems. There are many factors that continue to affect schools such as maintenance negligence, operating cost, aging buildings, decline in student enrolment, academic pressures, development pressures and consolidation (Wiebe, 2010). School closures and redevelopment have received a great deal of media attention in North America.
There are numerous surplus school properties in Toronto that have already gone through the process of adaptive reuse or demolition. However, there are still many schools that remain abandoned and more schools that continue to face endangerment across the city.

Unoccupied schools are deemed as surplus schools that no longer need to be used as educational facilities.

Therefore, surplus schools' properties are leased or sold to create revenue for school boards. The Toronto District School Board (TDSB) created a separate entity called Toronto Lands Corporation (TLC) to deal with managing and disposing surplus properties to generate revenue. Neighborhoods are significantly impacted both socially and physically thus; there are political pressures to 
maintain school properties as public ownership (Rasanu, 2012).

This thesis will address school closures in Toronto. In addition, to gain an understanding of the magnitude of the issue, Ontario will also be analyzed.

Toronto is the largest city in Canada and the Toronto District School Board is the fourth largest public school board in North America and the largest in Canada. Due to the staggering school closures Toronto is facing, the geographical scope of this thesis is the Toronto District School Board. Specifically, this thesis focuses on one Toronto school closure in the Fairbank neighborhood, Briar Hill Junior Public School. 


\section{THE PROBLEM}

Public schools across Canada are continuing to face declining enrolment and budget cuts encouraging school closures and consolidation. There are many factors that continue to affect schools such as maintenance negligence, operating cost, aging buildings, declining student enrolment, academic pressures, development pressures and consolidation. The line graph below illustrates the continuing decline in average enrolment in Ontario's elementary schools from 1999 to 2009 (Rasanu, 2012).
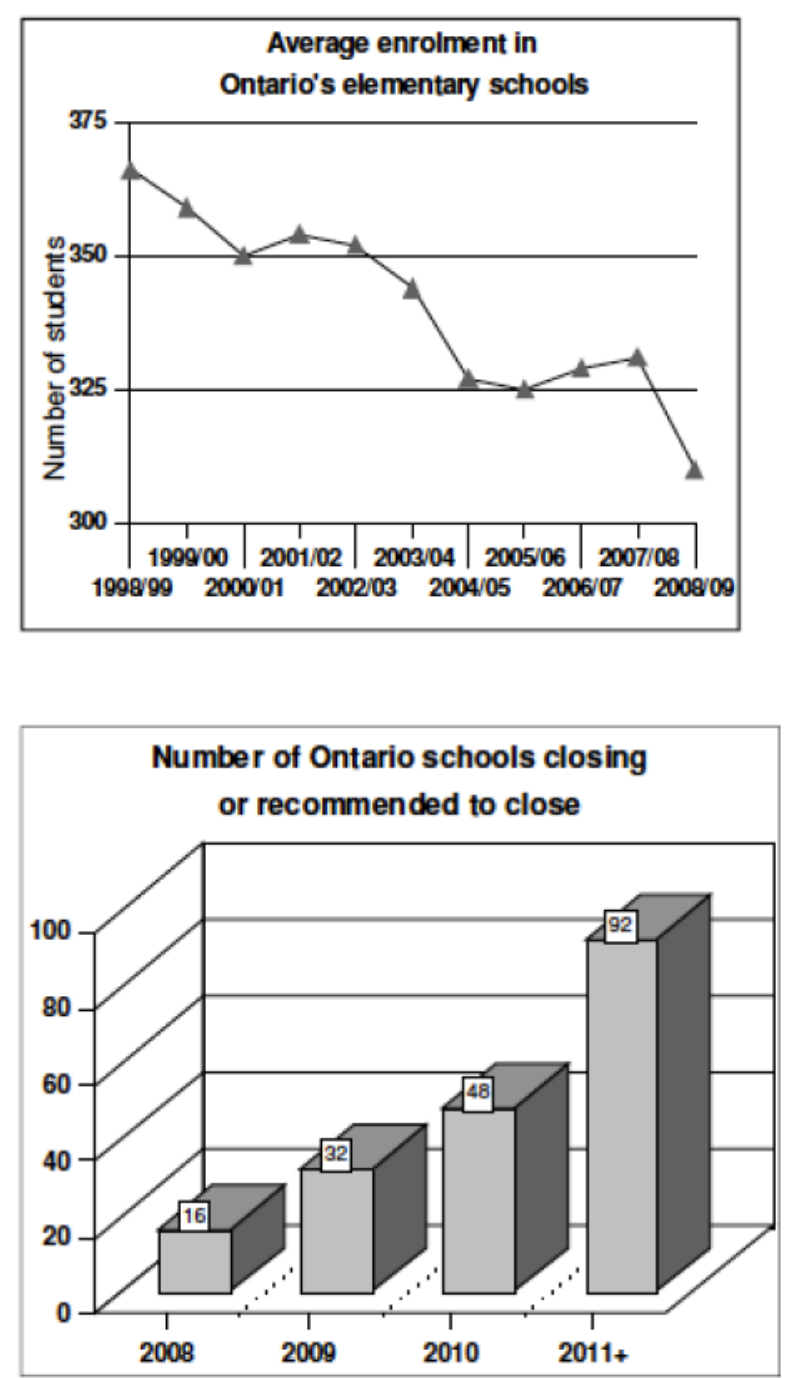

Figure 1: School Closures Statistics 
Schools in older neighborhoods across the country are taking the hit. The first intense wave of school closures was between 1999 and 2002 where approximately 200 Ontario schools were closed. Many people believe the reason behind these massive school closures were the neoliberal education reform policies. These policies eliminiated tax base funding for schools. Therefore, schools are solely dependent on funding from the Ministry of Education, student enrollment, and special project grants. The second wave was approximately 170 school closures, which occurred between 2009 and 2012 (Rasanu, 2012). The bar graph below illustrates the number of Ontario schools closing or recommended to close down between 2008 and 2011. This graph demonstrates that the numbers are continuing to rise (People for Education, 2007).

School closures are increasing, as a result, it is not only the loss of existing structures that occurs but it is the viability of a community in many cases. In rural areas, many might believe there is a larger impact because of the further proximity of schools. In urban areas, even though schools are in closer proximity, communities struggle due to the loss of a community hub. Declining enrolment is a national challenge because of the declining birth rate as well as due to an increasing aging population (People for Education, 2007).

Toronto is known as one of the oldest neighborhoods facing staggering school closures. The Toronto District School Board (TDSB) is the fourth largest 
public school board in North America and the largest in

Canada. Student enrolment has also influenced whether schools stay open or not, between 2007 and 2008 the student population has declined by 4000 in Toronto (TCL, 2011). The TDSB is the largest public school board in Canada which consists of over 600 schools and educates over 250000 students every year. The TDSB stated, "we will need much less space" due to declining student enrolment. Funding for school boards is received through the enrollment based funding formula. Therefore, TDSB needs to generate their own revenue to fund construction projects by selling surplus school properties and reinvesting. The TDSB has created a separate entity to deal with the surplus property sites called Toronto Lands Corporation (Rasanu, 2012).
Small schools across the provinces are more likely to close down. Over the last 25 years school enrollment has been decreasing and will continue to do so. The reason for so many schools being built in the 1950s and 1960s was due to baby boomers. There are many benefits of smaller schools such as increased student achievement, attendance and graduation rates, school safety and parent and community involvement. Smaller schools create intimate environments allowing for better communication and meaningful relationships for students, teachers and parents (People for Education, 2005).

The school closure process is not a simple one but one that requires countless decision making policies before it actually closes down. School closures create heated situations between community members and 
school boards. Many residents are impacted from school closures. [5]People wonder how schools are evaluated in order to see which schools are closed, consolidated or upgraded. Many poorer communities feel that they are in double jeopardy because poorer schools are singled out first. When looking at statistics, schools that are under review for closure are in the poorer half of the spectrum. When schools from richer neighborhoods are under review for closure, parents take on more active roles in attending meetings and participating in the process.

Poorer neighborhoods do not participate in the process because parents have additional jobs or inadequate childcare, therefore, their voices are not heard. The lack of participation allows schools in poorer communities to be closed easier and faster (Dyson, 2010). Even though, there is some community involvement in the decision making process the final decision is of the board's. Residents feel that the board has already made up their mind before the public even gets involved (FreduaKwarteng, 2005).

\section{CURRENT SOLUTIONS TO SCHOOL CLOSURES}

School closures take place for many reasons. School closures do not only result in the loss of historic structures, but also in the loss of community meeting places, playfields for children and green spaces. In some situations, it is financially sustainable to close down existing schools and build a new school in its place. In other situations, it is more effective to close down two existing schools and build one larger school. The current solutions for school closures are renovations, adaptive 
reuse and demolitions. However, many schools are easily demolished and the other two options are not frequently used (People for Education, 2009). The cost of refurbishment is a challenge to schools because funding is provided if the building renovation cost is below the replace value. The consequences of these factors leave schools abandoned and unoccupied. These sites can be considered desirable for future development; however, many are simply demolished due to time and money.

School districts understand the value of school properties so selling them has become a form of revenue to many school boards (Archer, 2009).

Many people have the misconception that the reuse of existing buildings is expensive to maintain and operate. However many are not aware "the greenest building is always the already built building". The amount of natural resources used to demolish and construct a new building is enormous in terms of energy, money and manpower. Ultimately, adaptive reuse requires fewer resources than new construction. Adaptive reuse is a process of reusing an existing site or structure for a different purpose or function other than what it was originally designed for. Many buildings are subject to adaptive reuse because of the continuous gentrification of places over time. As a result, the old purpose of the building no longer serves the existing demographic of the area. Repurposing existing schools allows historic structures to remain and continues to keep older communities active (Toole, 2012) 
There are a variety of options for the alternative use of surplus schools. The use is mainly based on the neighborhood and community the particular school is located in. Studies have shown an easier and inexpensive alternative for the use of surplus schools is to use them for neglected groups of people such as children or adults with physical and mental disabilities or adults who need vocational training and education. Public spaces such as recreational centers, libraries, and youth or elderly clubs are also other ways in which these schools can be used as community hubs. There are numerous examples of adaptive reuse projects of schools across the country, where they are converted into other educational facilities, community centers or residential developments based on the uniqueness of each individual site (Archer, 2009).

\section{PRECEDENCE}

ARTSCAPEYOUNGPLACE MULTI DIMENSIONAL

CENTRE, TORONTO, ONTARIO

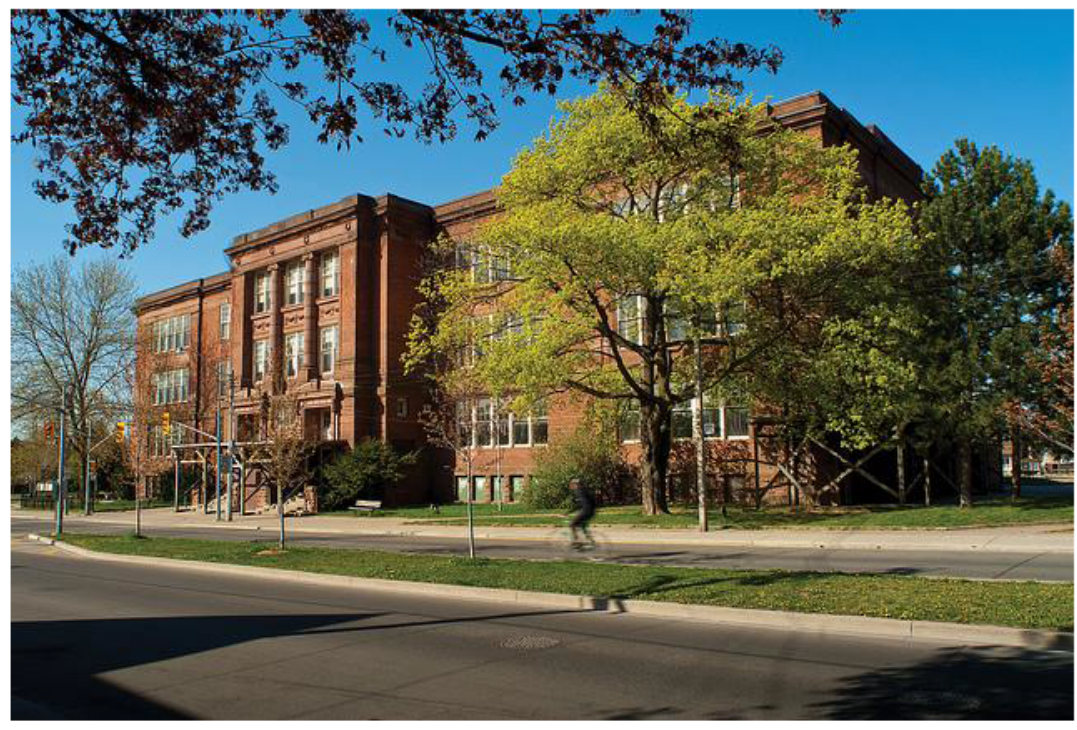

Figure 2: Artscape Youngplace Centre 
The Artscape Youngplace Multi Dimensional

Centre is located in Toronto, Ontario. This building was originally constructed in 1914 and functioned as an elementary school, formerly known as Shaw Public School. Later, the school was deemed surplus property and closed down in 2001. The school was later purchased by Artscape in 2010 and was an adaptive reuse project that was completed in 2012 . This building was repurposed as a multi-use center because of the population that lived in this neighborhood. The building was designed mainly as a centre for the arts and for community use, specifically to be utilized by youth. This building was a community hub for the residents and they supported the reopening of the building. The community had a lot of input in the decision making process of the design and function of the building. The main functions of this building are studio spaces, long term and short term rentals, learning labs, coffee pub, urban living lounge and hallway gallery spaces (Kohn, 2011).

In terms of renovations all of the mechanical, electrical and plumbing systems were changed. There were several elements restored such as the exterior sandstone walls and interior elements. There was also incorporation of new landscaping and more accessible buildings to all users. Many of the academic fixtures were adapted into the new spaces such as chalkboards, cork boards, beadboard walls, and cubby holes. The large open spaces for example the gymnasium and library had an abundant amount of natural daylight into the building 
and these spaces were used as public spaces (Yu, 2013).

GOODES HALL, QUEEN'S SCHOOL OF BUSINESS,

KINGSTON, ONTARIO

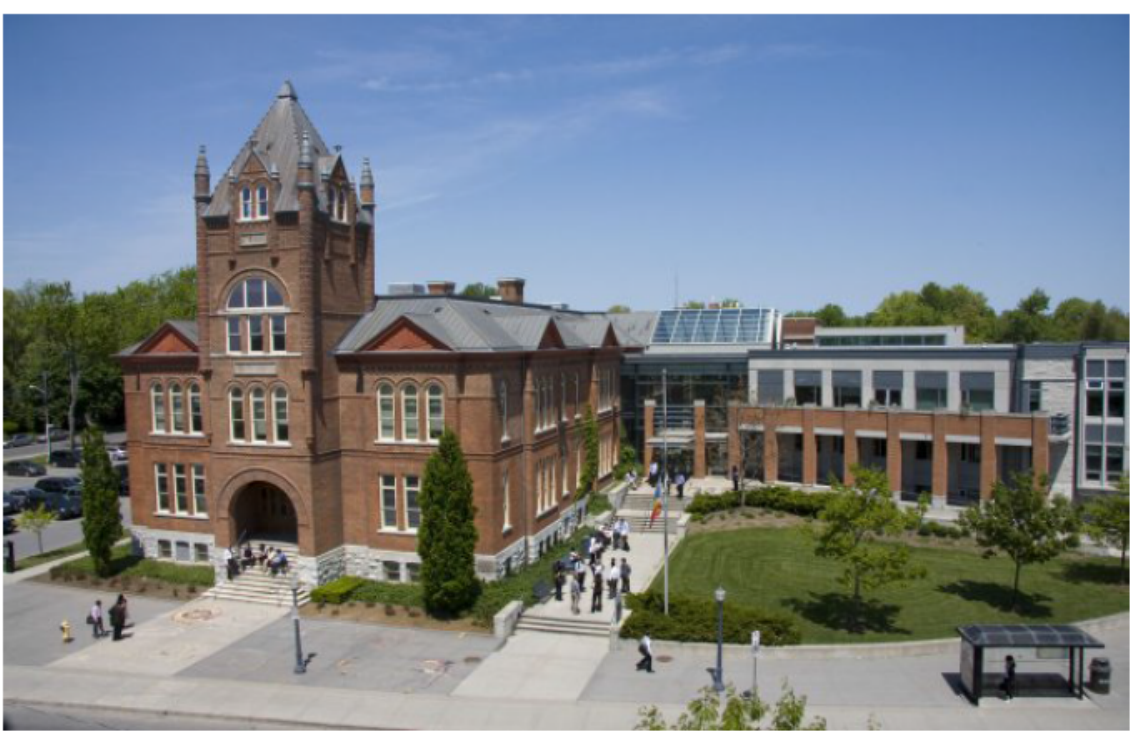

Figure 3: Goodes Hall, Queen's University

Goodes Hall is the school of Business within

Queen's University in Kingston, Ontario. This existing school was built in 1892 and was used as a school until 1985. In the 1990s Queen's University purchased the school and it was used as the Registrar's Office for several years. The building went through an adaptive reuse process and became home to the School of Business in 2012. The School of Business facility consists of renovating the existing 45,000 square foot school with an addition of a 143,000 square foot structure. The building has several amenities such as classrooms, study rooms, faculty offices and food services (Queen's University, 2012).

Ventin Group was the lead architect for this adaptive reuse building. The design intentions were to blend the old with the new by preserving historical elements but also incorporating new contemporary 
architecture. The original school was a Victorian style schoolhouse. There were several elements that were preserved from the original school such as the slate blackboards, grand maple staircase, main exterior entrance doors, maple wainscoting and tin ceiling. The architecture of Goodes Halls was coherent with the university's philosophy of "construction with respect for history and the belief that new buildings should be tastefully integrated with the historic surroundings of Kingston, Ontario" (Peets, 2013). 


\section{ADAPTIVE REUSE BACKGROUND}

Architecture, urban planning and the construction industry have become more environmentally conscious. Sustainability has become a major concern to many professionals as a result of climate change, increase in air pollution, reduction of natural resources and erosion of the natural ecosystem. The construction industry consumes a great deal of resources and produces large quantities of waste and emission. Therefore, the traditional methods used in the construction industry have been reevaluated and more sustainable designs and practices are being established (Toole, 2012).

Many people have the misconception that the reuse of existing buildings is expensive to maintain and operate. However, many are not aware "the greenest building is always the already built building". The amount of natural resources used to demolish and construct a new building is enormous in terms of energy, money and manpower. Ultimately, adaptive reuse requires fewer resources than new construction (Dyson, 2010).

One sustainable design practice is adaptive reuse. Adaptive reuse is a form of sustainable practice that preserves the life of the structure by integrating different transformations. Adaptive reuse is defined as a process through which the structural framework of the building is retained, while the building, which may include the exterior and/or the interior, is renovated or modified in order to perform a new function or support a new use (Toole, 2012). Adaptive reuse projects commonly incorporate five principles into the design, these include: 
- Well performed for the design intended

- Function for a long period of time with the adaptability for new uses

- Enhance and respect the existing neighborhood fabric

- Create visual coherence with the existing structure and is an aesthetically pleasing environment for users and pedestrians

- Create sustainable structures that prevent minimal environmental impact

Adaptive reuse projects are all different therefore; require time and dedication to understand the project and create original solutions. There are several advantages of adaptive reuse projects such as environmental, social and economic benefits. The environmental benefits are the reuse and recycle of the existing building materials that in return reduces the amount of waste in landfills.

Older buildings are created from more durable materials therefore the lifespan of these materials is longer. Also, older buildings have a lot more windows that are beneficial for cooling and heating. These buildings are already incorporated into the existing public infrastructure grid therefore reduce environmental impact and urban sprawl. Reusing an existing structure is a sustainable approach that reduces the natural resources, emissions, embodied energy and energy use (Rasanu, 2012).

The social benefits are preserving the heritage and culture of the building. Heritage preservation refers to linking both cultural and architectural heritage of the structure. Preservation refers to maintaining the existing 
fabric, whereas, conservation refers to maintaining the cultural significance of the place. Preserving the architectural style of the building or the fabric can increase character-defining elements of the structure, streetscape and/or the neighborhood. These elements are key in identifying the cultural, historical and environmental value of the area.

Adaptive reuse is an appealing solution for communities that are evolving in terms of demographics, habits, needs and wants of the residents. Adaptive reuse strategies revitalize the local community and support intensification. Changing neighborhoods provide an opportunity for new niches to benefit from the social and economic development of the area (Toole, 2012).

Maintaining an existing structure continues to reinforce a sense of place for communities. Preserving existing structures and highlighted architectural features meanwhile adapting to the new environment creates a diverse community with a variety of building types and styles. Preserving existing architecture strengthens the collective community identity and local architectural fabric of the neighborhood (Rasanu, 2012).

The economic benefit is the cost of adaptive reuse projects is usually less than demolition and new construction. Structures that are ignored because of social or economic changes in the community are considered a good financial investment when adaptive use is a solution instead of demolition and reconstruction. Adaptive reuse can be considered as an economic saving that enhances aesthetics and functionality 
qualities of existing structures. The municipality benefits from a higher property tax from an occupied space instead of a vacant building; it also, improves the property value and encourages local investment. The existing structures are already connected to the public transit therefore, reduces municipal infrastructure costs (Rasanu, 2012).

There are a few barriers to the adaptive reuse approach such as site remediation, structural soundness and local context. Site remediation is an important factor for adaptive reuse projects. Many existing structures contain harmful materials, which can include lead and asbestos. Other factors in site remediation are structural cleanup, accessibility and stability of the existing structures. Structures that are deteriorating can be considered a risky investment in terms of adaptive reuse when a building's performance and functionality are unknown or degrading. The local context such as zoning bylaws height, setbacks and size is important to consider for the design (Toole, 2012). 


\section{BACKGROUND INFORMATION}

\section{SCHOOLS AS BUILDING TYPOLOGY}

Kindergarten, primary and secondary institutions are important building typologies, and tend to be understudied. Classrooms, corridors and ancillary spaces are the main program spaces of schools. In 1848 Henry Barnard wrote about the importance of daylight, ventilation, adequate furniture and green spaces for good learning environments. Evolving educational theories, population sizes and changing neighborhoods schools are relatively constant in design. In the late eighteenth century, schools were one room schoolhouses; it was an open floor plan where students were all taught in one room.
During the Industrial Revolution era, these oneroom schools were considered inadequate due to an increase in the student population. Therefore, two to three floor schools were built with several rooms and a gymnasium. The first American example of a school that segregated students into different classrooms by age was Boston's Quincy Grammar School. This school was a key example for many other schools in the second half of the nineteenth century (Dyson, 2010). Schools were considered an example of factories with assembly lines. The teachers provide knowledge in the areas of math, science and languages. Once they obtain their knowledge they move to the next line, the next classroom. 
During the late nineteenth century and early twentieth century people wanted education to be experienced in a more individualized and board-based curriculum. Schools incorporated other program spaces for courses other than the "core" courses such as music, art, dance and gardening (Rasanu, 2012). Therefore, design and interior furnishing was changed. From fixed row seating arrangements, classrooms began to consist of movable furniture, larger rooms, and multipurpose rooms which were designed for activities. Schools in the postwar era were more innovative and functioned as a community center consisting of recreational, shop facility and large auditoriums. However, these schools were small-scale structures. Twentieth century constructed schools are still in relatively good condition and continue to function as it was intended to. Many of these schools are architecturally ordinary in style, but significant in other ways such as the social, cultural and historical aspects (Dyson, 2010).

\section{PERCEPTION OF OLD SCHOOLS}

Communities across Ontario have been struggling due to the loss of their schools. Older schools in particular are extremely valuable. Closing down older schools does not only take away a historic building in a neighborhood, but affects the character of the community. Enrollment rates have continuously been decreasing over the last 25 years. In one of the fastest growing cities in Canada, Toronto still does not have enough children attending public schools to keep the school sustainable. This is especially concerning for 
established neighborhoods with older schools because the demographic living in these areas are older.

Older schools need more maintenance and renovations, therefore, people take the easier solution. People believe older schools are designed for a different age of safety and fire codes and so are deemed as unsafe. Older schools are at a disadvantage for funding purposes by the government of Ontario. Ontario schools are funded by a funding formula that calculates amount of money given to a school by the number of student enrollments and gross area of the school. Although, older schools have more spacious programming such as higher ceilings and wider hallways they receive less funding. There is funding available for new construction by the Ministry of Education, but there is very little money allocated for restoration of existing schools (Archer, 2009) 


\section{LEGISLATIVE POLICIES}

\section{ADAPTIVE REUSE}

Adaptive reuse is sustainable practice and an alternative to demolition. Therefore, many governments support this design and practice. Like many countries, Canada has several municipalities that provide incentives for adaptive reuse projects. Both municipal and provincial legislation and policy govern land use development and planning. Some municipal incentives that provide funding are Ontario Heritage Foundation and SuperBuild. There are also grants provided such as property tax rebates and waived development fees.

Federal funding is available such as Millennium Fund \& Infrastructure Canada. There is also funding provided by the City of Toronto through the Toronto Heritage Grant
Program, Live Green Toronto Grant Program and Better Buildings Partnership.

PROVINCIAL POLICY STATEMENT FOR ADAPTIVE REUSE

The Provincial Policy Statement deals with the "provincial interest". The policy concerns are the quality of life for Ontarians with the efficient use of resources, protection of the natural environment and public health and safety. Some of the goals this policy addresses are: healthy and lively communities, cultural heritage preservation, encouraging variety of housing types and economic success, and stimulating intensification and redevelopment. This policy supports adaptive reuse because of the advantages of efficient resource 
consumption and preservation of culture and heritage.

See appendix for specific sections.

TORONTO OFFICIAL PLAN FOR ADAPTIVE REUSE

The Toronto Official Plan envisions the future of

the city and reassures development and land use

decisions that create diversity, richness, economic

benefits and long-term sustainability. The plan

encourages physical and social connectivity, cultural

celebration of heritage, environmental security and local

economic growth. The plan supports adaptive reuse in

terms of preservation of heritage, effective land use

development and economic growth. Please see

appendix for specific policies.

\section{SCHOOLS}

\section{PROVINCIAL FUNDING FORMULA}

School closures are mainly driven by provincial funding formulas, which funds public schools. The formula is based on the area requirement per student. Older schools are seen as inefficient because of the spaciousness of the building with high ceilings, wide hallways, and big rooms, as a result more energy is required. The typical box schools with lower ceilings; smaller rooms and smaller windows are considered more efficient. Older schools are definitely at a disadvantage compared to newer schools when calculating the funding formula. Although, the provincial government does provide the funding for schools, the final decision about 
school closures, sales and demolition is decided by the school board (Wiebe, 2010).

\section{CITY OF TORONTO OFFICIAL PLAN FOR SCHOOLS}

Historically the school board and the city have

preferred existing schools to be used for community purposes, especially for recreational and child care needs. The existing Toronto Official Plan states the preferred use of surplus schools in section 3.2.2. (Rasanu, 2012). Keeping surplus schools for community service purposes will be pursued where the need for such facilities has been identified as a priority. If this is not feasible, alternative uses of closed schools must be compatible with the surrounding neighborhood and should provide City residents with continued access to school playgrounds and playing fields. The council recognizes that schools are an integral community resource that serves not only as learning institutions but also as socio-cultural centres and a source of valuable community open space. The City will consider acquiring learning institutions as publicly owned sites for parks and open spaces.

\section{COMMUNITY USE POLICY}

Ontario school boards understand there is limited funding and encourage schools to be used for community use. This will continue to run schools and be vital community hubs for all ages. Schools can be used on weekday evenings and weekends to support community involvement. Community uses consist of many activities like community meeting spaces, after school programs, spaces for seniors, and daycares. Despite Ontario 
schools agreeing to this community use policy, there is a lot of discrepancy between the boards across the province. This is because there is not a consistent policy for all the boards across the province. Each individual school board determines what the prices of the spaces are and what use is acceptable. This creates inconsistency between community groups and therefore, people feel it is unfair and it is not used widely (People of Education, 2007).

\section{ONTARIO REGULATION 444/98}

The Ontario Regulation $444 / 98$ is a framework Ontario school boards utilize in order to decide what they want to do with surplus properties. School boards must follow provincially mandated assessment of all schools when deciding budget savings. School boards go through the Accommodation Review Committee to determine if a school is deemed as surplus. This committee conducts public consultations, assesses the situation and makes recommendations to the board. Based on the assessment and recommendation the board decides whether or not to close the school (Rasanu, 2012).

The Regulation 444/98, Disposition of Surplus Real Property of the Education Act, manages the disposal of surplus property. The board first and foremost distributes a surplus declaration notice to public agencies such as other school boards and educational and government establishments (Rasanu, 2012). The schools are offered to other school boards in the area such as the catholic board, private schools and alternative schools. If none of these school boards are interested in the 
property, the school is offered to the municipality. The

provincial then the federal level of government has the

opportunity to purchase the property. It is encouraged to

keep the school building and the site as public use

especially as community centers or learning facilities

(Archer, 2009). These public agencies have the

opportunity to purchase or lease the property within 90

days before opening the bid to the general public. The

following image is a flow chart showing the Toronto

District School Board and the Toronto Land Corporation

Disposition Framework (Rasanu, 2012).
ARC Recommendations School Not Required

TDSB Board Aprroval: Surplus Declaration with Disposition Parameters for Sale or Lease

TLC Lead: Discovery Session with Public Partners

\section{Regulation 444/98 Circulation}

Disposition Options:1)Lease 2)Joint redevelopment with public agency or private development partner

$$
\text { 3)Direct sale }
$$

Negotiate a Development agreement \& agreement of purchase \& sale

\section{TCL Board Approval}

TLC oversee and manage planning approval process \& development partner, if applicable

Figure 4: Toronto District School Board and the Toronto Land Corporation Disposition Framework 


\section{NEIGHBORHOOD ANALYSIS}

\section{GEOGRAPHICAL CONTEXT}

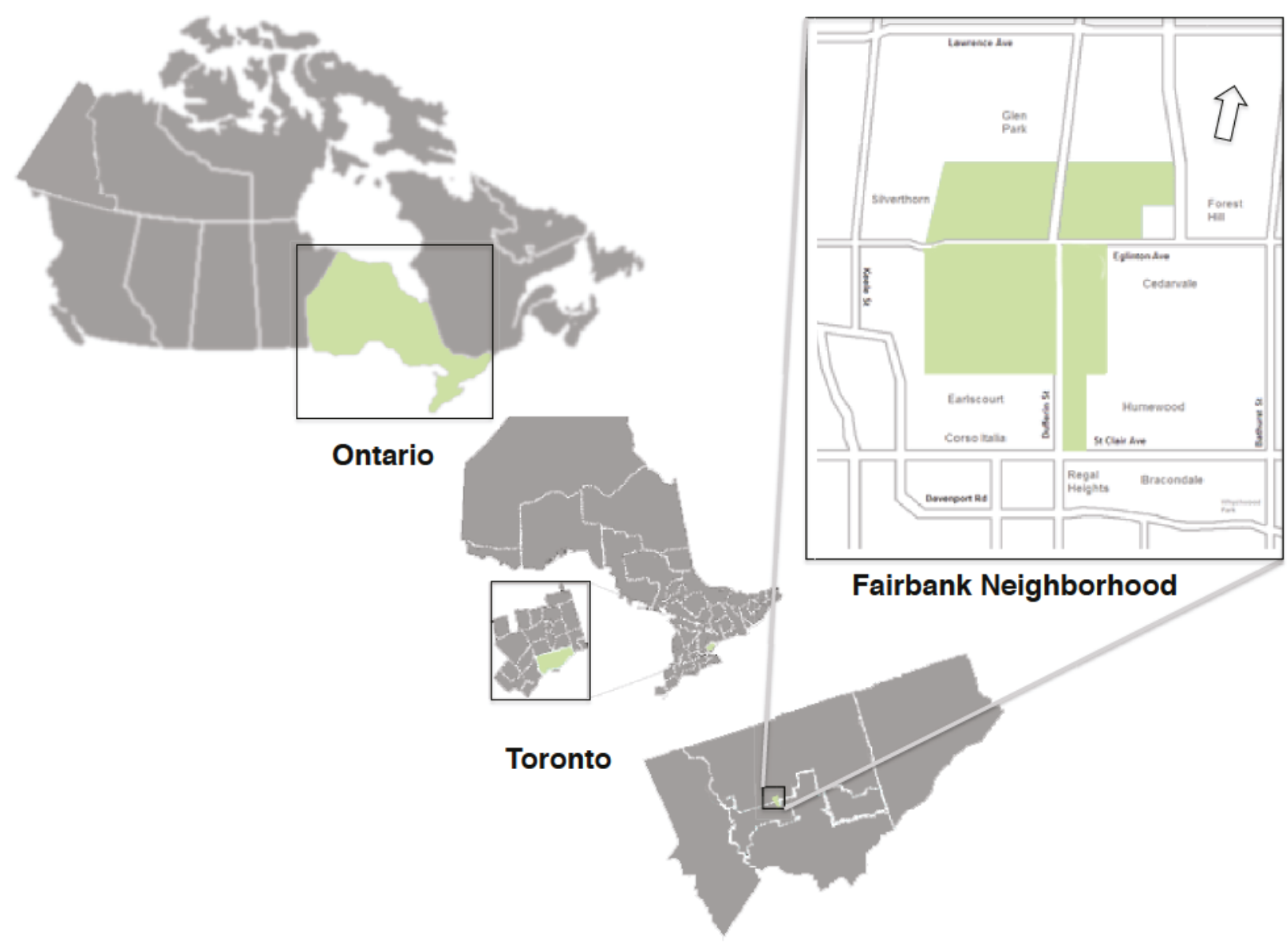

Figure 5: Geographical Location 
Fairbank is considered a historic neighborhood in the city of Toronto. Fairbank is situated in the center of the intersection of Dufferin Street and Eglinton Avenue. The neighborhood is a large part of the former city of York, Ontario. The neighborhood is located between Dufferin north of St. Clair Avenue, stretching to the north of Eglinton Avenue and ends on the west of the $\mathrm{CN}$ rail line (Fredua-Kwarteng, 2005). The topography is this neighborhood is unique with rolling hills towards the northward from Rogers Road to Briar Hill Avenue. These hills created curvilinear streets and this area consists of many one-way streets, which add to the olden day character of the neighborhood.

The existing land use map below illustrates the different building uses in the Fairbank neighborhood. The map exemplifies in yellow the highly residential spaces with mixed-use areas on the main intersection of Dufferin Street and Eglinton Avenue. The residential fabric of the neighborhood consists of a mix of smaller prewar homes, post war brick and stucco homes and a combination of bungalows and two-storey homes. There are apartments located on periphery of the neighborhood. On the west of Dufferin Street there are dense portions of employment areas shown in purple, which consist of a mix of offices, retail and service buildings(People of Education, 2007).

People might believe the original historic buildings disappeared over the years with continuing development of this neighborhood. However, when the neighborhood is examined closely, there are several historic buildings scattered across the area that are still present today. 
Some of the historic buildings that stand today are the united church, the legion, a residential street, two schools, a community center, a park and a local gentleman's club. There are several landmarks in this neighborhood such as, Prospect Cemetery Fairbank Memorial Park, Fairbank Memorial Community School, Fairbank Middle School, FH Miller Junior Public School, St. Hilda's Retirement Residence, St. Hilda's Anglican Church, St. John Bosco and St. Thomas Aquinas (McNulty, 2014). The Eglinton and Dufferin region is also known as the business improvement area. Eglinton Avenue consists of little Jamaica and West Indian stores and restaurants. There are several Toronto Transit Commission bus routes in the Fairbank neighborhood such as 29 Dufferin, 32 Eglinton West, 47 Lansdowne alongside Caledonia road, and the 109 Ranee alongside Marlee Avenue (during daytime hours), and 307 Eglinton West and 329 Dufferin (during nighttime hours). There are no subway lines passing through the neighborhood, however, there are two stations that are in walking distance such as Glencairn Station and Eglinton West Station (People for Education, 2009). 


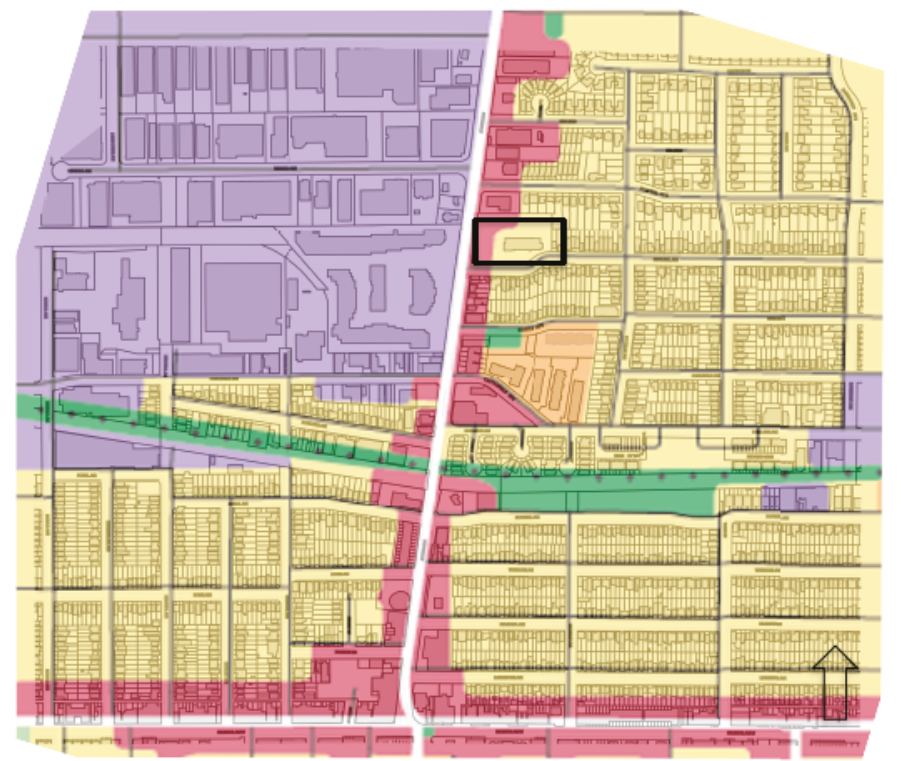

landuse map

Employment Areas

Mixed Use Areas

Neighborhoods Apartment Neighborhoods

Figure 6: Landuse Map

The Fairbank neighborhood has several facilities that serve as social hubs for the community. There are several schools that educate the community these include, four elementary schools, one middle school, four catholic elementary schools, two high schools, and two public libraries. There are two large parks in the community, which are Fairbanks Memorial Park and Earlscourt Park. Fairbanks Memorial Park has a community center attached to the park. The community center has programs for both children and adults (People for Education, 2009). Fairbank Memorial Park is known as one of the landmarks in the community. It consists of 9 acres of park and a recreational center. The park contains a baby pool, a large pool, snack area, sport fields and playground (McNulty, 2014). 


\section{SCHOOL CLOSURE IN THE COMMUNITY}

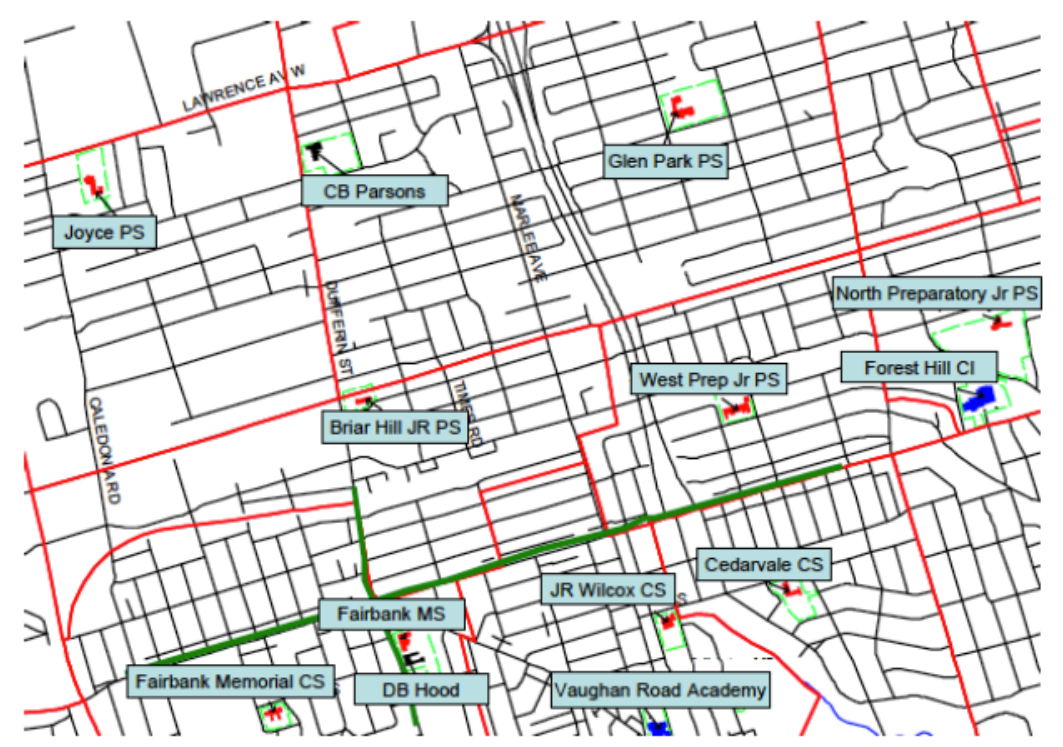

Figure 7: Map of Schools in the Area

Schools in the Fairbank community were under consideration for future development. The TDSB reviewed three schools in the area, Briar Hill Junior Public School, Fairbank Middle School and West Preparatory Junior Public School. These schools were examined and reviewed by the accommodation review committee, which consisted of school staff, parents and community members. There were several months of meetings, debates and reviews before a final decision was made for the future outlook of these schools (Rasanu, 2012).

Residents and parents of Briar Hill Junior Public School attended and participated in several public meetings held between 2009 and 2012 regarding the closure of their small elementary school. The community consisted of lower income immigrant families who loved and valued the importance of a school in their neighborhood. Many of the community members felt that the board targeted lower income neighborhoods when it came to school closures (Dyson, 2010). 
Howard Goodman, the TDSB trustee for the region of Eglinton-Lawrence considered several alternative options to keep the elementary school in the neighborhood. One option he strongly suggested to the board was continuing to use it as an elementary school for grades from junior kindergarten to grade 3 and redevelop the remaining part of the school into residential and commercial space. The students in grades 4 to 6 would be transferred to Fairbank Middle School. The board disapproved this alternative solution and wanted to sell the property. There were many ideas about the idea of high-rise residential developments with the combination of commercial use (Dyson, 2010).

The TDSB considers schools at full capacity when at least $80 \%$ capacity is met. When looking at the future of the schools in the Fairbank community, statistics illustrate there will be continuous decline in student enrolment. If Briar Hill and Fairbank continue to function the way they do, this will be an unsustainable option for these two schools in the future. The schools will be under capacity, Fairbank at $43 \%$ and Briar Hill at $68 \%$. By closing down Briar Hill and integrating the student population into Fairbank the enrolment rate will increase to $82 \%$. When analyzing the costs to keep these schools open, Briar Hill is estimated to cost $\$ 200,000$ annually for operational costs and \$4 million for repairs by 2018 . Renovation of both of the other schools will cost \$3.6 million and selling Briar Hill will allow for a new form of revenue coming into the school board (Rasanu, 2012). 
The final decision was made to:

- Close Briar Hill Junior Public School

- Convert Fairbank Middle School into a k- 8 school

- Continue West Preparatory Junior Public School without no change

There was a lot of outrage and disappointment with parents and community members when the final decision was made. A few local people spoke out.

Gabriela Gonzalez, local parent, said, "I think the funding formula is what needs to be scrapped, not our schools". Another local resident said, "The process for the arc was highly undemocratic and highly patronizing. We are just going through the motions and it was done probably so that in the future the TDSB can say they consulted the community and that's why they made these decisions, whether they work out or not in the future (Rasanu, 2012)."

The decision to close Briar Hill Junior Public School created concerns for many residents and parents. Safety was a major concern, young children would be travelling a further distance to their elementary school, and in particular they would be crossing the busy intersection of Dufferin Street and Eglinton Avenue, which is unsafe. The school as a community hub and the use of green space as interaction between neighbors is taken away. Also, the value of a small school experience for young children is lost (Toole, 2012). 


\section{EVOLUTION OF THE NEIGHBORHOOD}

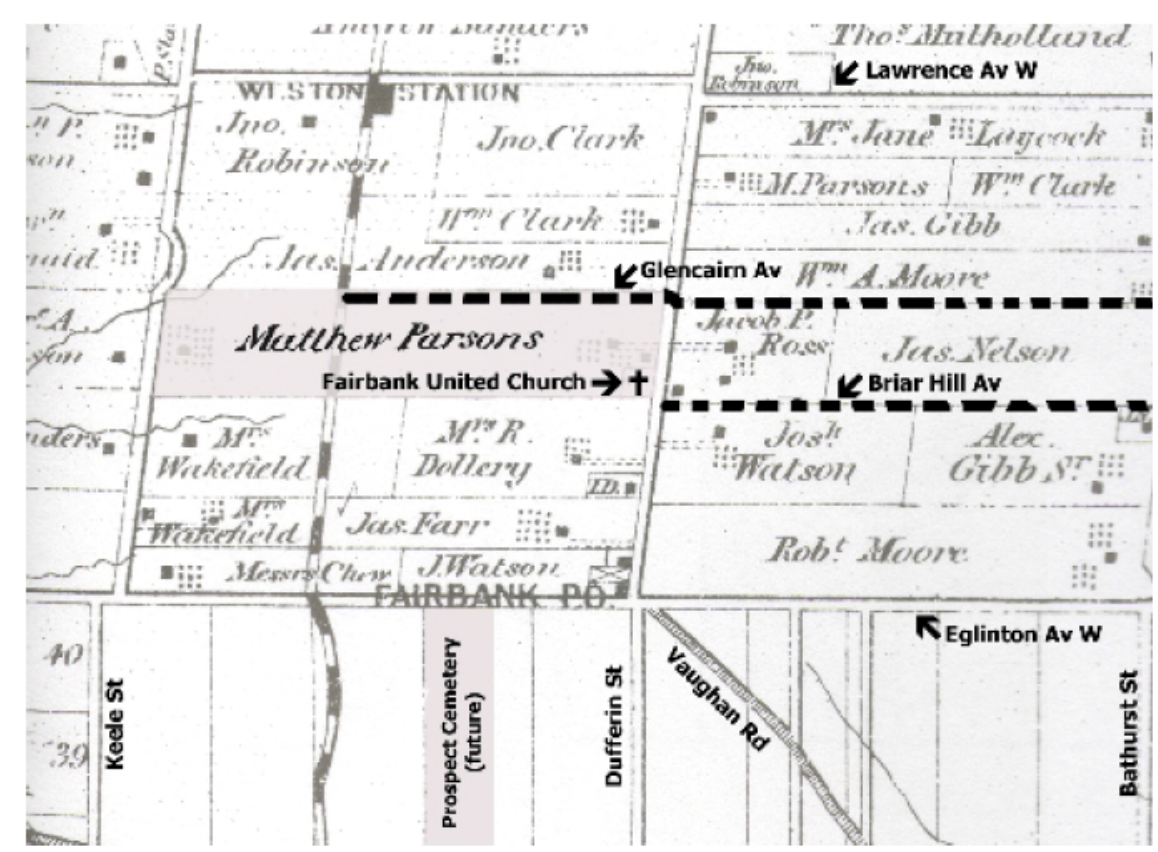

Figure 8: Fairbank Map in 1878

The Fairbank area was known as the Fairbank

Postal Village, when early settlers came across the area

through the farmlands of the Vaughan Township.

Although, Fairbank never was given the "village" status, it is considered one of the lost villages of Toronto (People for Education, 2009). The name Fairbank was from Matthew Parsons' farm called "Fairbank's farm" and was located in the Eglinton Avenue West and Dufferin Street area. Today it is simply known as "Fairbank". Matthew purchased land in the Fairbank area in 1835, soon after people followed into this area. There was a group of residents who settled into this area by the 1860s. In the 1870s, development started across Toronto as well as in the Fairbank neighborhood. Service buildings were built in the Fairbank area. The map below shows the existing condition in 1878 , and the dash shows the existing condition today.

In the late 1880s, the Toronto belt line company was created as a form of transportation for people living 
in the suburbs and Fairbank had a stop on the beltway; soon after Fairbank was considered a suburb area. In the 1860s a one room school was constructed for the residents of Fairbank, in 1889 the Fairbank Methodist Church was created and today it is known as the Fairbank United Church. The village was part of the York West Township until 1953 when it became part of metropolitan Toronto. In 1998 it was incorporated as a part of the City of Toronto (Archer, 2009). Eglinton Avenue and Dufferin Street transformed over the years from a residential area to a major suburban arterial with the combination of residential and industrial regions. Most of today's existing neighborhood fabric was built in the 1920 s and 1930s with a large population of residential homes. The following years, businesses started being built along Dufferin Street People for Education, 2009). Since the 1950s and 1960s, Dufferin Street has been converted into a mixture of strip plazas, stores and car dealerships.

The population sizes of Ontario's urban and suburban area have changed rapidly over the last few decades. The population shifted from urban to suburban areas and increased from the $20^{\text {th }}$ century. Due to the increase in population these suburban areas are referred to as "inner city". These inner cities are facing strains to the existing public services such as transit, childcare, housing and public education. Fairbank is considered one of these inner cities (Billespartners, 2013). 


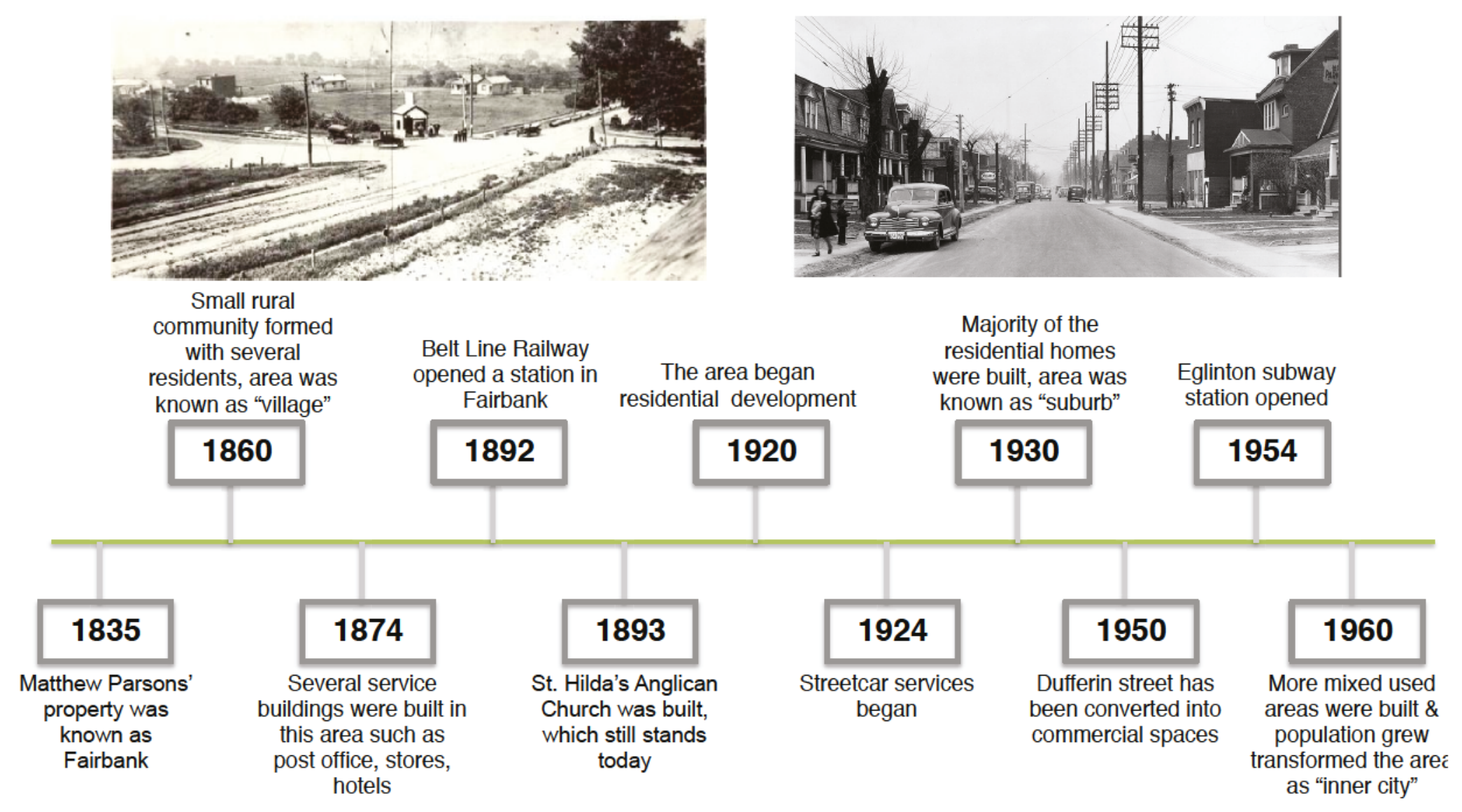

Figure 9: Fairbank Evolution Timeline 


\section{DEMOGRAPHICS STUDIES}

Analyzing the demographics in the Fairbank neighborhood provides a better understanding of the community and the residents. The pie graph below illustrates the different percentage of age groups that occupy this neighborhood. The largest age group is the working class (ages 25 to 65 ) that make up $61 \%$ of the population; the rest of the population is divided up by 13 $\%$ seniors (ages 65 and older), $14 \%$ children (ages 0 to 14 ), and $12 \%$ youth (ages 15 to 24 ).

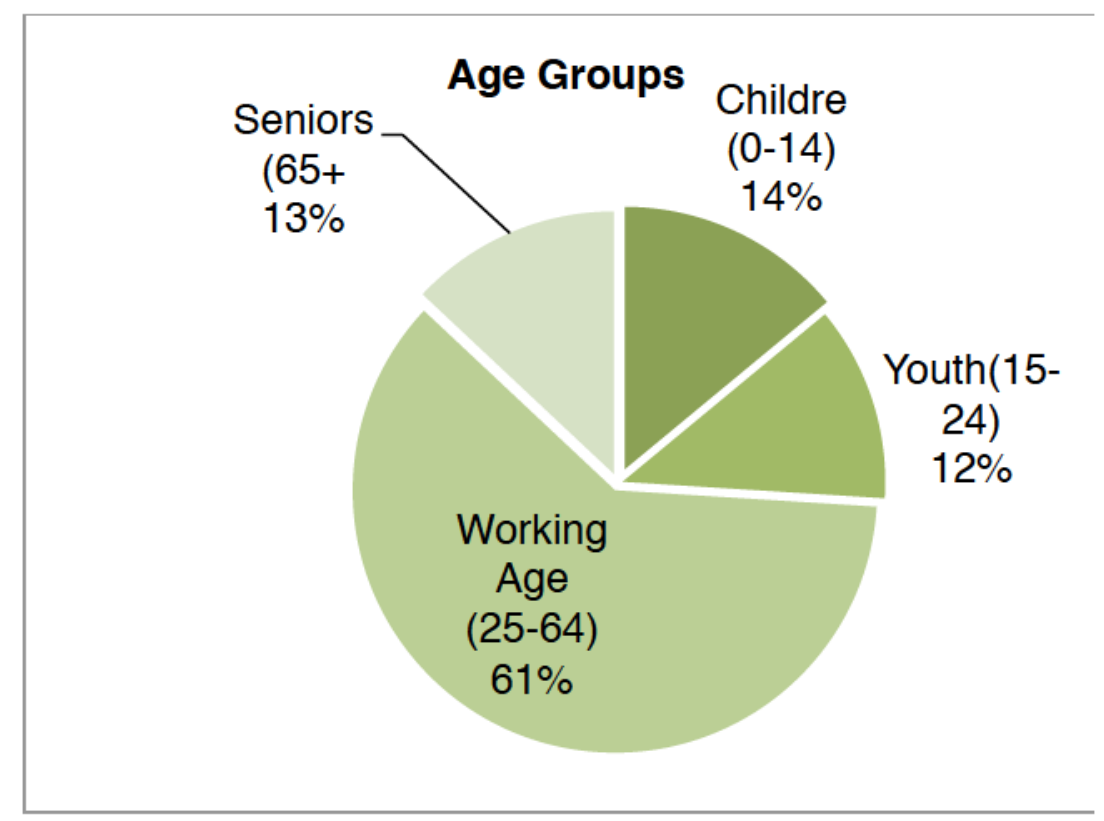

Figure 10: Demographics Statistic 


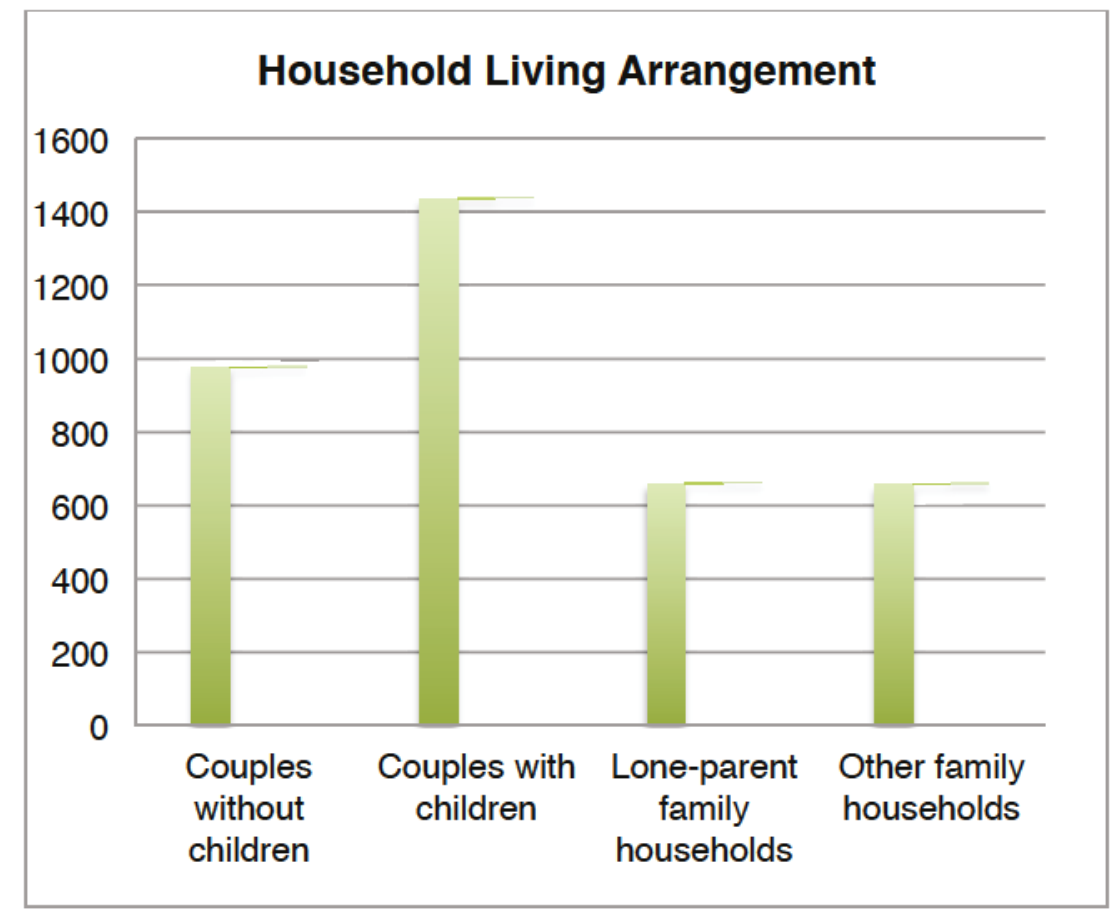

Figure 11: Demographics Statistic

The household living arrangement in the neighborhood is illustrated in the bar graph below. This graph is divided into four sections: couples without children, couples with children, lone parent family households and other family households. The highest living arrangement is couple with children and second highest is couples without children. The population of women $(54 \%)$ is slightly higher than men $(46 \%)$ in this community.

The pie graph shows various mother tongues in this community. This community consists of more than half, approximately $57 \%$, of immigrants with non-official mother tongues. There is about $38 \%$ of the population whose mother tongue is English and the remaining 5\% consist of French and other languages as their mother tongue. The table clarifies the top 5 non-official mother tongues spoken in this neighborhood which are: Tagalog 8.3\%, Portuguese $7.7 \%$, Italian $7.1 \%$, Spanish $5.6 \%$ and Russian $4.2 \%$. 
Top 20 Non-Official Mother Tongue Languages

\begin{tabular}{lrc} 
& \multicolumn{3}{c}{ \# of People } \\
Tagalog (Pilipino, Filipino) & 1,190 & $8.3 \%$ \\
\hline Portuguese & 1,100 & $7.7 \%$ \\
\hline Italian & 1,020 & $7.1 \%$ \\
\hline Spanish & 800 & $5.6 \%$ \\
\hline Russian & 600 & $4.2 \%$ \\
\hline
\end{tabular}

Figure 12: Demographics Statistic

The dwelling units are examined in a larger

geographical area. The neighborhood consists of lowrise structures. This neighborhood is highly residential with $30 \%$ single detached houses and $45 \%$ of apartment buildings under 5 storeys. There are few semi-detached and row houses, however it is not that common in this particular region. There are also a few apartment buildings more than 5 storeys high.

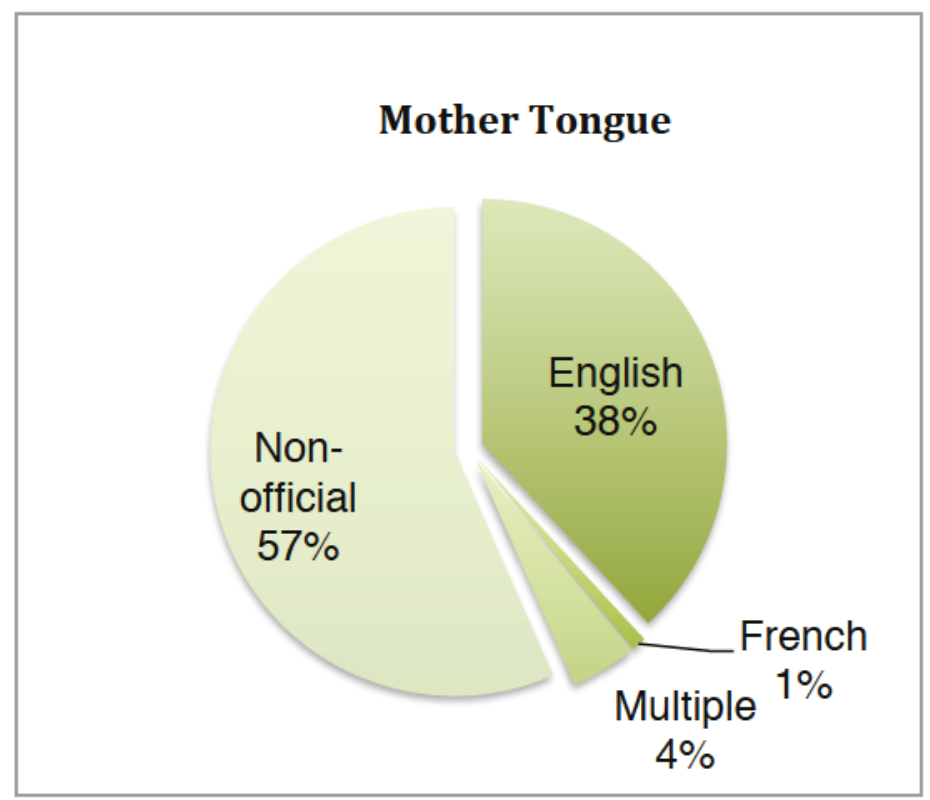




\section{SITE ANALYSIS}

\section{GEOGRAPHICAL CONTEXT}

Briar Hill Junior Public School is located at the corner of Briar Hill Avenue and Dufferin Street. The site is situated on Dufferin Street and highly accessible to the public. The neighbourhood is a major suburban area with mostly residential houses. However, as it is located on a major street, the site consists of strip plazas, commercial spaces and factories. The property consists of approximately 2.4 acres with a three-storey brick schoolhouse. The southwest portion of the property has a fenced playground area. The site has several mature trees throughout the property.

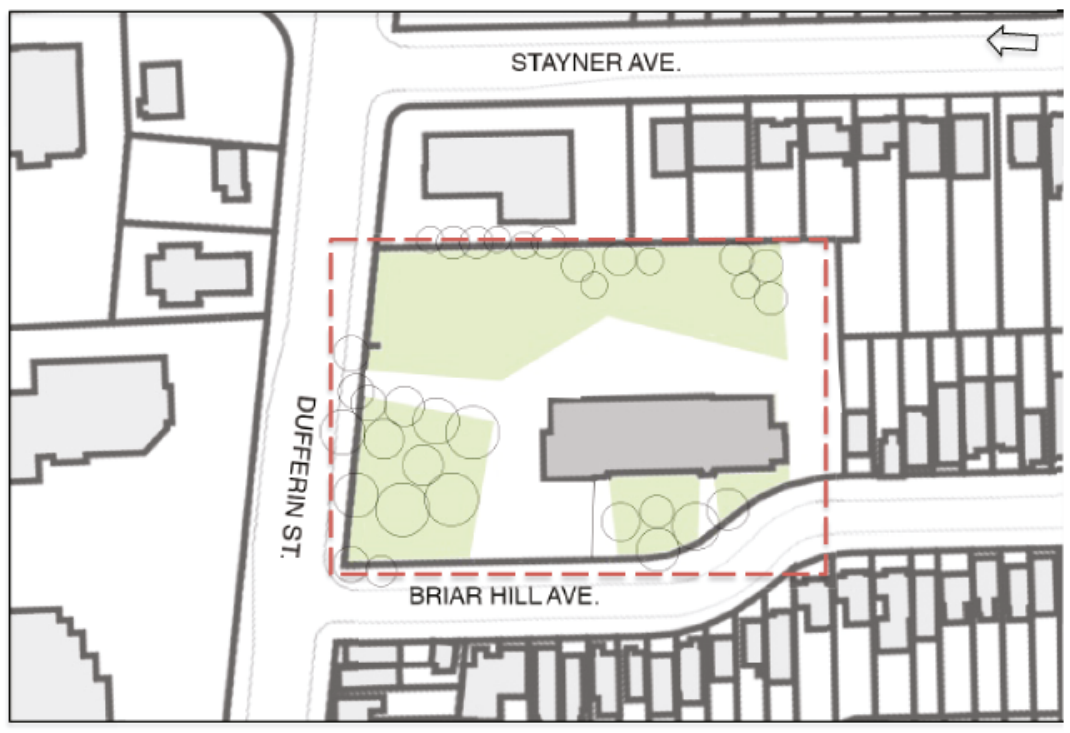

Figure 13: Briar Hill Junior Public School Area Map

north: automotive repair \& car wash

east: one \& two storey detached homes

south: one \& two storey detached homes

west: dufferin business centre which contains a mix of office, retail \& service uses 


\section{BUILDING HISTORY}

One of the historic landmarks in the Fairbank neighborhood is the Fairbank Public School. The school was a landmark and community hub for the residents of this area. Many residents felt the absence of this school when it was deemed 'surplus' and closed. The school was originally built in 1927 as a two-storey brick structure. Over time, with the changing neighbourhood and increase in population the school expanded into a larger footprint. In 1956, the first addition to the existing school was the east side two storey addition and a west side one-storey addition. In 1969, a second addition to the one-story northwest corner was constructed. This site served as a school for nearly a century until it closed in 2012. Being closed for over a year with no maintenance the school started to disrepair.

The original school built in 1927 was a two-storey red brick structure that resembled school architecture in the $20^{\text {th }}$ century. The front façade of the school consists of two symmetrical highly decorative entrances with the separation for girls and boys. This was a common institutional architectural element in the 1920s with separate entrances for male and females. Other elements of institutional architecture are enormous tall windows with detailed craftsmanship surrounding the openings and line clerestory windows in the basement to provide light into the lower level (City of Toronto, 2014). 

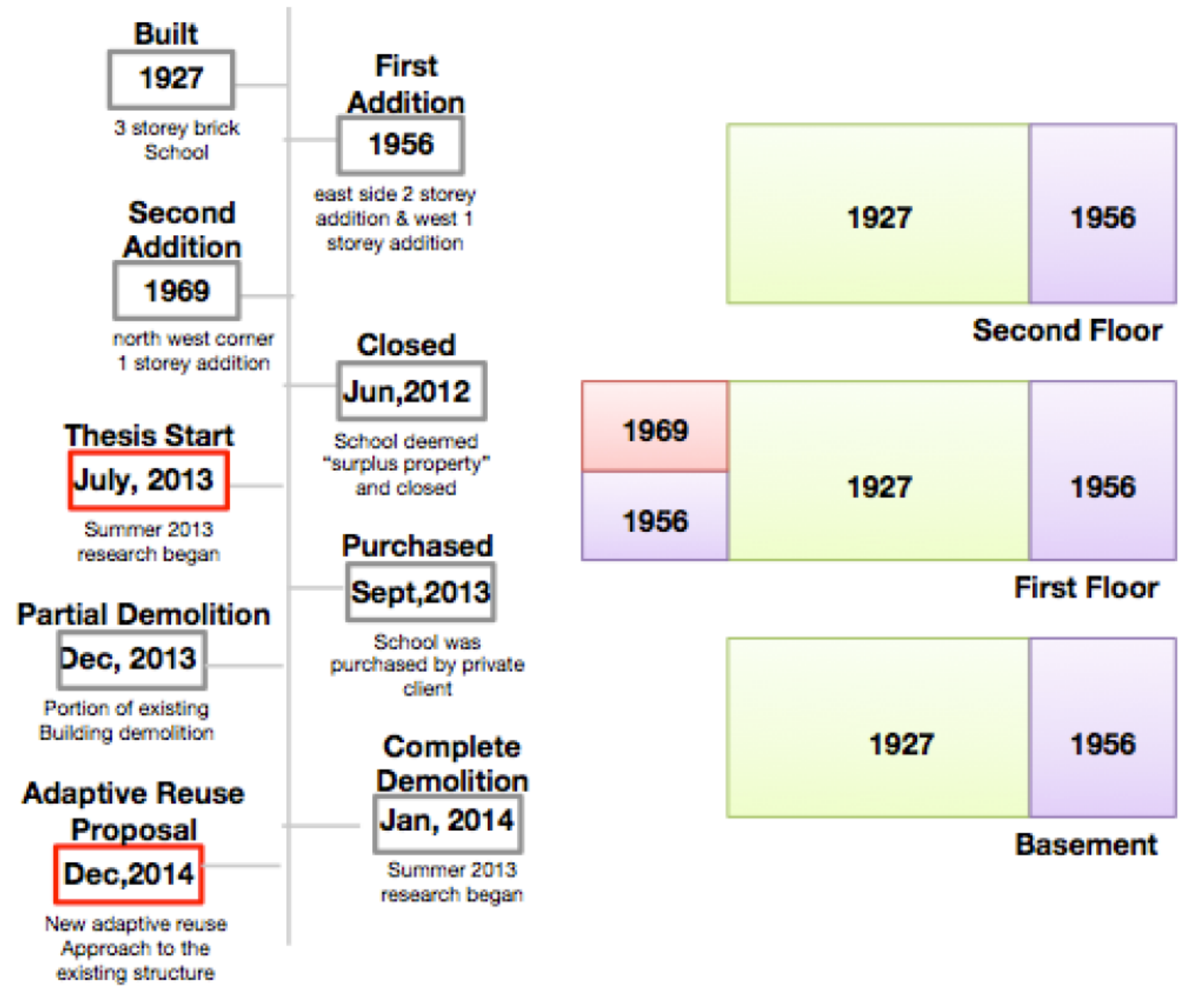

Figure 14: Briar Hill Junior Public School Evolution Timeline 


\section{CHARACTER DEFINING ELEMENTS}

Schools are important to create a sense of community for neighbourhoods. Some schools have a great deal of detail and craftsmanship whereas others may not have a high degree of craftsmanship. This does not mean these schools should be undervalued. There are combinations of character defining values such as architectural, cultural, ecological, economical and urbanistical. The table below explains the different character defining elements of this building.

\section{CULTURAL ELEMENTS}

The school is a landmark and historic structure in the neighbourhood. However, it is more than a historic structure, it is a site that has been used for decades. It has been accessible to the public as a communitymeeting place, playfields for children and park land.

\section{ECONOMICAL ELEMENTS}

The school provides children a place to play and learn during school and after school hours and during evening and weekend classes. A school in the neighbourhood that provides extra services allows children to have a short and safe trip to these extra curriculum activities, this is also beneficial for the adults in the neighbourhood attending leisure and learning classes.

\section{ARCHITECTURAL/ HERITAGE ELEMENTS}

The vital elements of the building are: historical decorative arch exterior entrances, a plaque with the 
school name, a stone craved plaque for the girls and boys entrance on the south façade, character of the windows, multicolor exterior walls differentiating the constructed time periods and interior artwork on the walls.

On the south façade, the primary element is the central portion of the building, which has the greatest volume that identifies the main entrances into the building. The two main entrances are highly decorative with a great deal of craftsmanship with stone-carved plaques above the archway indicating males and females. The windows follow a rhythmic placement on this façade, which is similar to the north façade. The 1920 portion of the building consists of symmetry whereas the later additions of the building create an imbalance in size and height.

On the west façade, there is a secondary entrance with a one storey projection from the original school.

There are smaller windows aligned in a row. Also, there is a large plaque of the school's name on the corner right hand side of the wall. The original portion of the school has a large central window at the end of the hallway. On the corner portion of the school the multicolor exterior brick colors are visible. The interior of the school has artwork on the walls, which defines the character and the use of the space.

\section{SPATIAL ELEMENTS}

The main circulation is the central axis to the building and it runs east to west. The main entrances of the building are on the south side, with minor entrances 
on the west side of the building. The vertical circulation is based on the two central staircases. The first and second floors are primarily classrooms. The basement consists of playrooms and a gymnasium. 


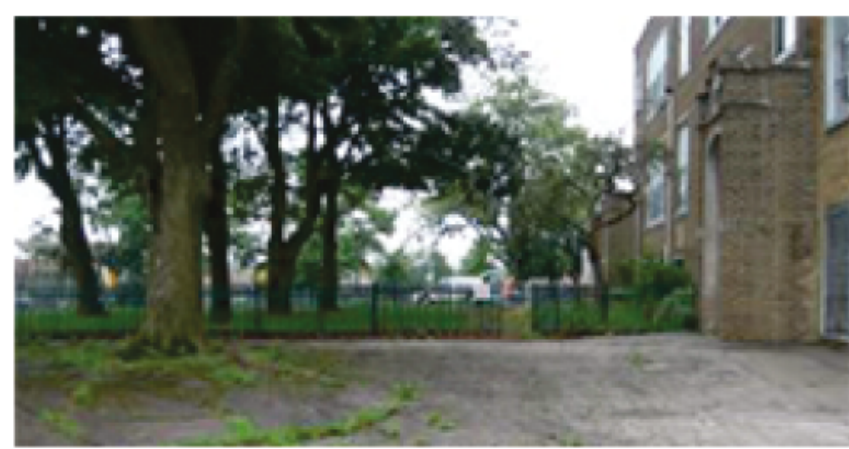

multicolor exterior walls to differentiate time periods

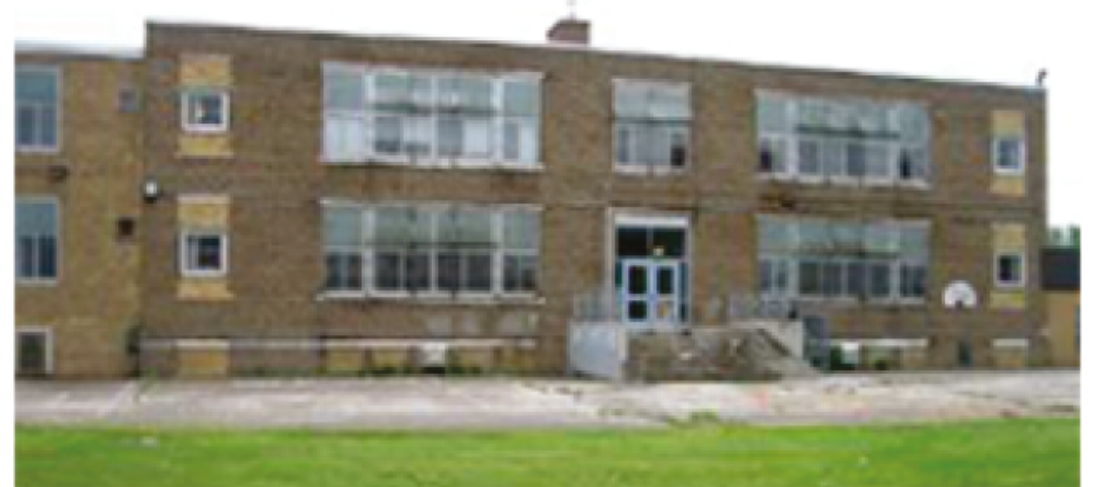

multicolor exterior walls to differentiate time periods

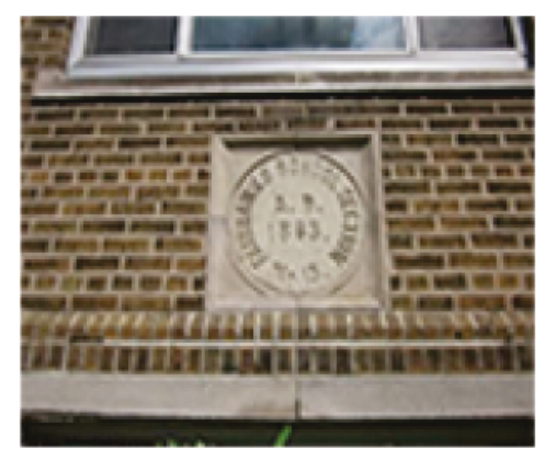

stone craved plaque

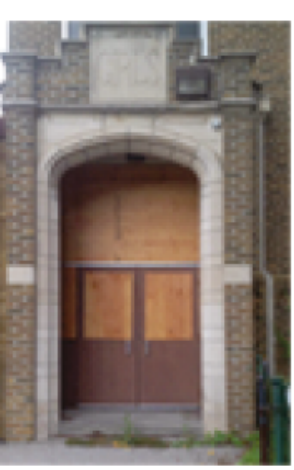

historical decorative arch exterior entrances with plaque of the girls \& boy

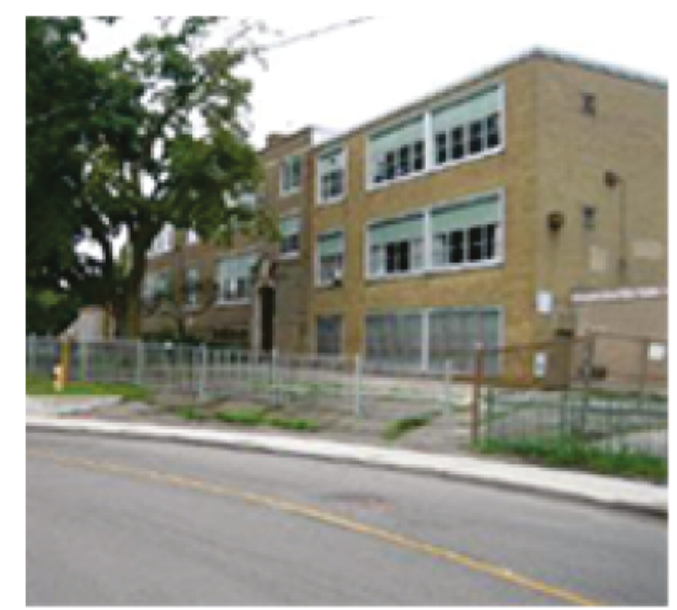

historical decorative arch exterior entrances

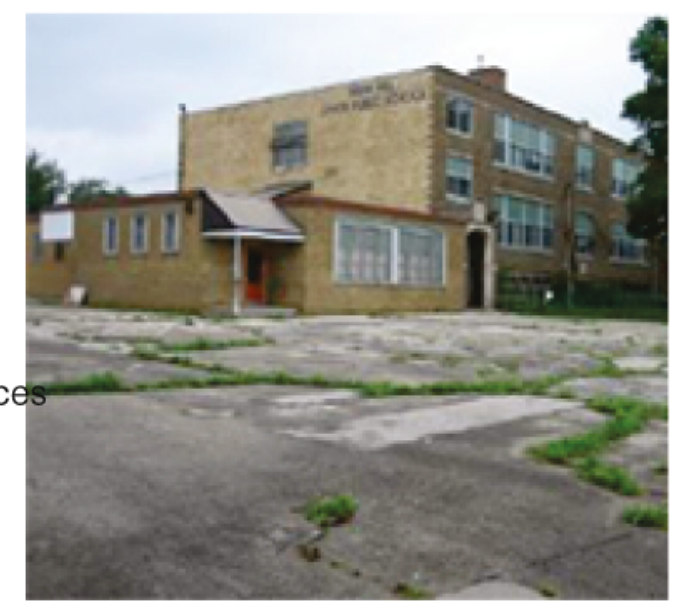

plaque of the school name

Figure 25: Character Defining Elements 


\section{CLIENT REQUIRMENTS}

This design proposal is implemented through the participatory design approach. This approach is defined by community engagement and key findings determined by community meetings, surveys and interviews. The views and opinions of the area residents drive the design strategies. These different forms of data collection provided a combination of feedback and opinions from the residents in order to gain a better understanding. The community engagement findings were the key elements used to determine the program and design of the building. The community wanted the site to be used as public space and the green spaces to be maintained as it was for centuries. The community wanted the converted site to respect the existing fabric of the neighborhood.
The program of this building was determined by what the community felt was lacking in their neighborhood and what they thought would be utilized to the fullest capacities. Based on the tabulation of the results, demographics and neighbourhood analysis, it is clear the residents wanted a community center incorporating particular programmatic areas such as recreational, social spaces, meeting rooms and a library.

The results from the participatory design approach determined the programmatic spaces of the community center. The program for this design involves a diverse set of spaces that accommodate a variety of activities for the users. There are six programmatic areas these include learning spaces, event spaces, creation labs, library, recreational spaces and outdoor spaces. The building 
consists of three floors. The ground level consists of a large atrium, garden and kitchenette classroom; a majority of the large rentable spaces are event, meeting and workshop rooms. The lower level consists of recreational spaces and creation labs such as woodshop, metal shop and pottery rooms. The upper level consists of library and exhibition/gallery space.

The future vision of this building is to continue running as a community center. The advantage of a community center is that it has the capabilities to transform into multiple uses as the neighbourhood transforms. As the demographics change, the uses within the community center will accommodate the current residents. This community has been a residential district for decades and will continue to be so. Due to the

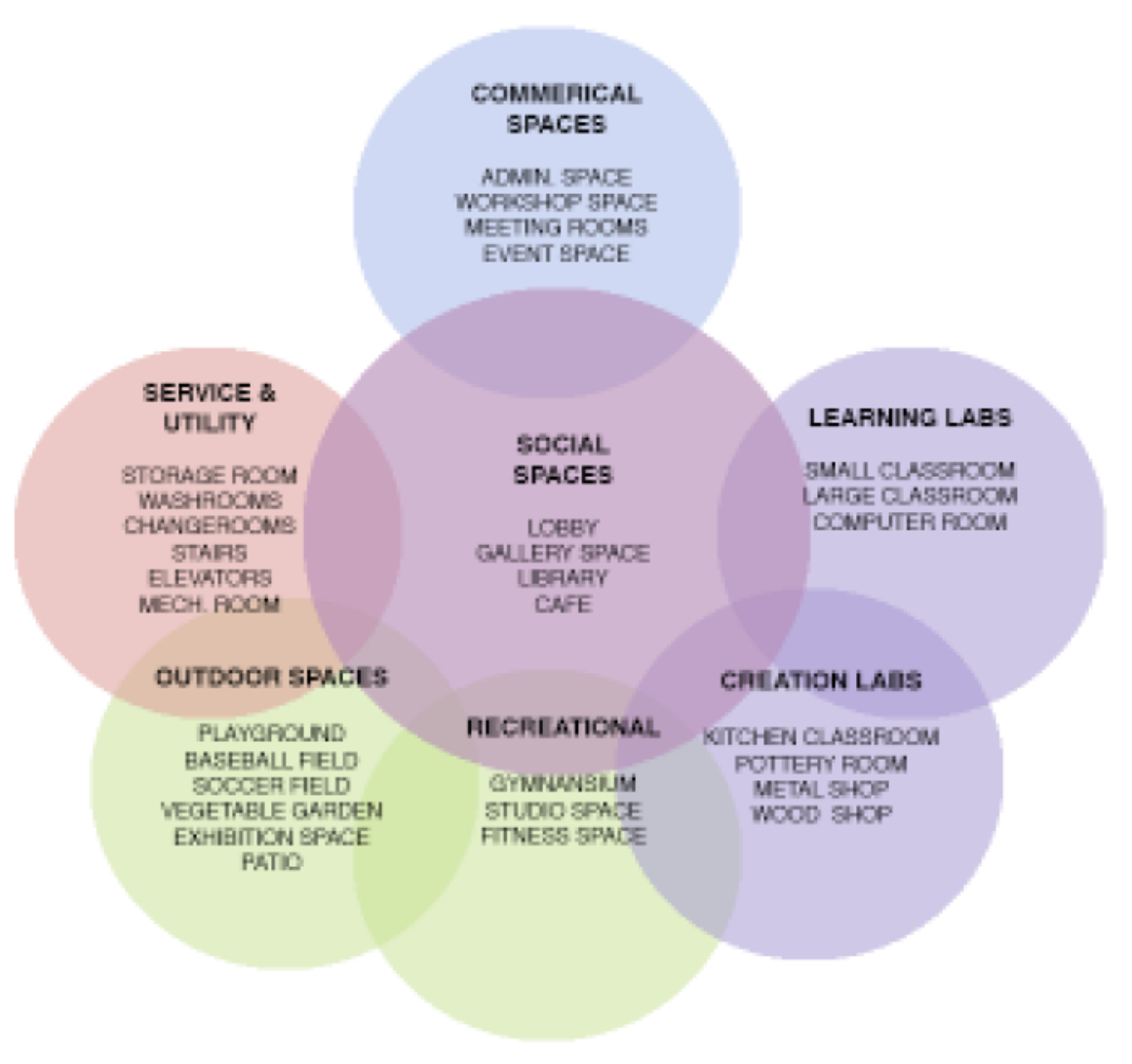

Figure 16: Bubble Diagram for Program Spaces

spacious land there is always room to create additional spaces in this area. 


\section{TRANSFORMATION \& PALIMPSEST}

\section{CONCEPT}

\section{Transformation [the continuum]}

"It (design/architectural process) is the outcome of participating in the process of cultural transformation that comprises construction and destruction. Some things, however, remain. We store bits and pieces here and there inside us that perhaps, later, someone will collect; and they leave signs in space and in people that fuse together in a process of transformation. We then put these pieces together, creating an intermediate space and converting it into an image, and we invest them with meaning so that each piece means something in light of the others."

\section{- Alvaro Siza}

Alvaro Siza explains that architecture does not have to be a permanent form, like everything else it transforms over time adapting to the changing environment. The process consists of construction and destruction, where pieces from different time periods merge together to form a whole (Vander, 2014).

Palimpsest is defined as, "to write again after the original has been effaced; to overwrite." In terms of architecture palimpsest can be redefined as, " a structure characterized by superimposed features produced at two or more distinct periods". In other words, palimpsest means adding layerings of history to a building, which can be transformed differently over time. Palimpsest can be architecturally demonstrated in diverse forms of design concepts. The following are precedents, which illustrate the transformation and palimpsest approach to architecture (Crenshaw, 2013). 
NEUES MUSEUM

DAVID CHIPPERFIELD \& JULIAN HARRAP

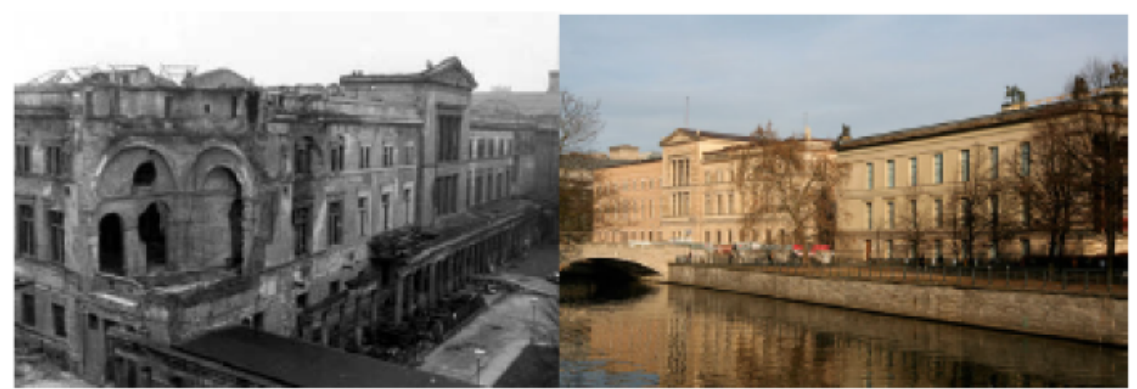

Figure 17: Neues Museum Exterior

The Neues Museum in Berlin was originally built in 1841 and later renovated in 1857 by Friedrich August

Stuler. In 1997 David Chipperfield Architects in

collaboration with Julian Harrap redesigned the museum.

The aim of the design was to respect the historical

structure by restoring and repairing the original volume

and materials. Many portions of the original structure

were destroyed due to the World War Two bombings.

There were minimum repairs, majority of the building was unused and exposed to nature. Therefore, many spaces were restored to the original condition to continue the historic fabric of the building (Etherington, 2009). The contemporary elements with new program spaces distinctively illustrate the new from the old. David Chipperfield recreates pieces of the past structure into more sculptural elements, which enriches the memory and the history of the original building. The following images are examples of areas of the building that have been altered (David Chipperfield Architects, 2009).

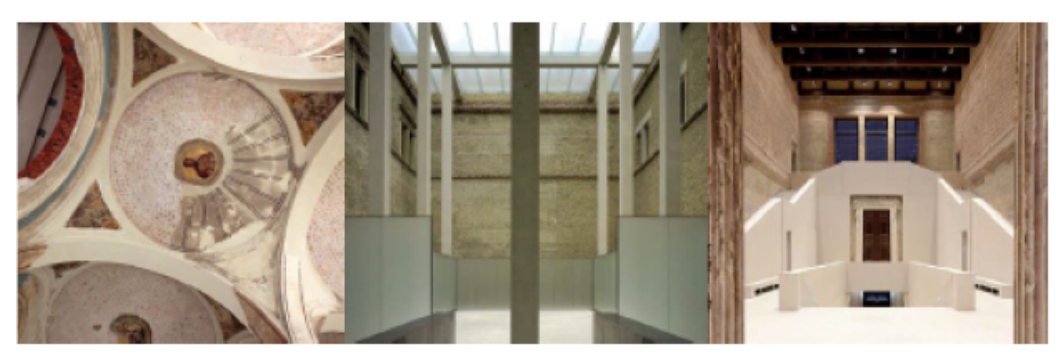

Figure 18: Neues Museum Interior 
HEDMARK COUNTY MUSEUM

SVERRE FEHN

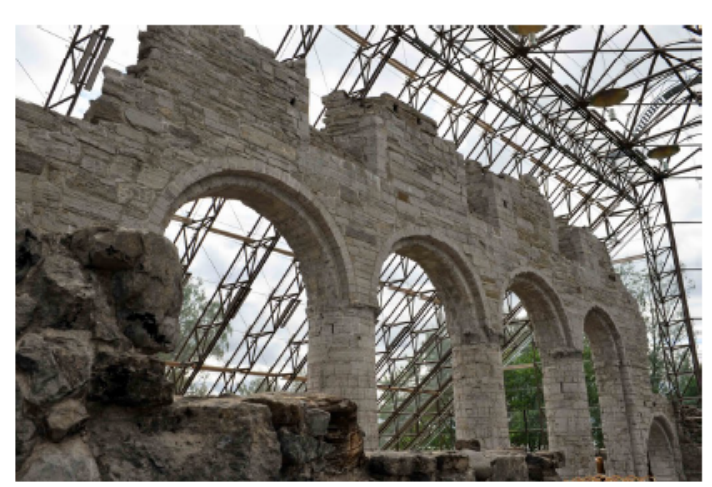

Figure 19: Hedmark County Museum Interior

Hedmark Country Museum is located in Norway

and was renovated by Sverre Fehn. This structure was altered and repurposed over several time periods. The

original structure was the Romanesque Cathedral in the 1500s. Later it was converted into a Gothic style building. Sverre Fehn redesigned an adaptive reuse museum exposing the ruins by interconnecting it to new pieces of architecture. He distinctively connected the old and new with different materials. The old material consists of stone whereas the new materials consist of wood and glass.

Fehn's interpretation of palimpsest does not reproduce existing elements of buildings instead inserts layers of history by combining new pieces into existing pieces. The following images are an illustration of how the old materials are woven into the new materials (Arch Daily, 2011).

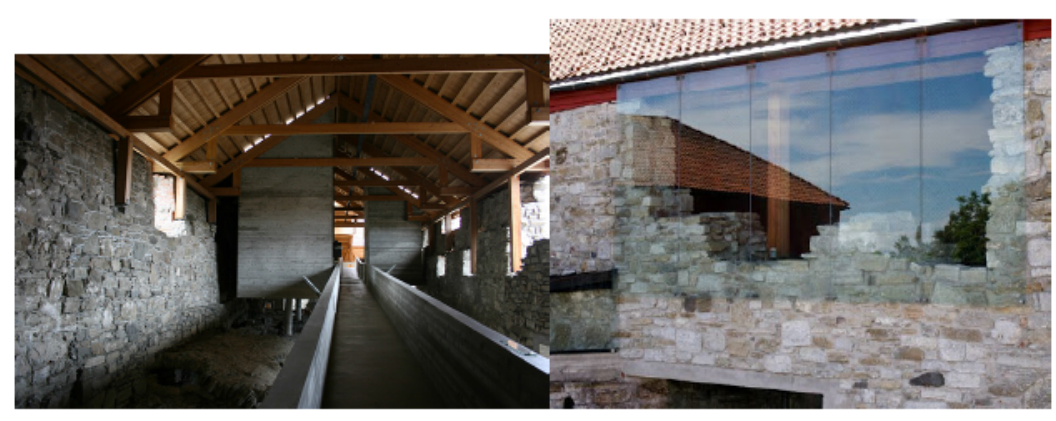

Figure 20: Hedmark County Museum Details 
CASTELVECCHIO

CARLO SCARPA

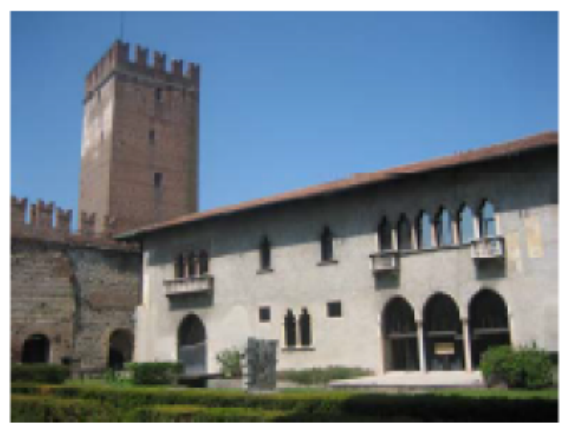

Figure 21: Castelvecchio Exterior

Castelvecchio is located in Verona, Italy and was repurposed by Carlo Scarpa. Castelvecchio was originally a castle for a medieval family built in 1356; it was later converted into a church. In the eighteenth century the castle was converted into a museum. Due to World War II, parts of the building were bombed. In 1957, Scarpa redesigned the existing structure by expressing modern architecture using materials such as concrete, wood and steel. He juxtaposes the present with the past. Different parts of the building are revealed to illustrate the different time periods that exist. Scarpa had a different approach towards expressing the architecture by not restoring the missing pieces of the building. Instead, he joins new pieces of architecture into the existing building. The following images of ceilings, walls and floors are examples of Scarpa's approach.

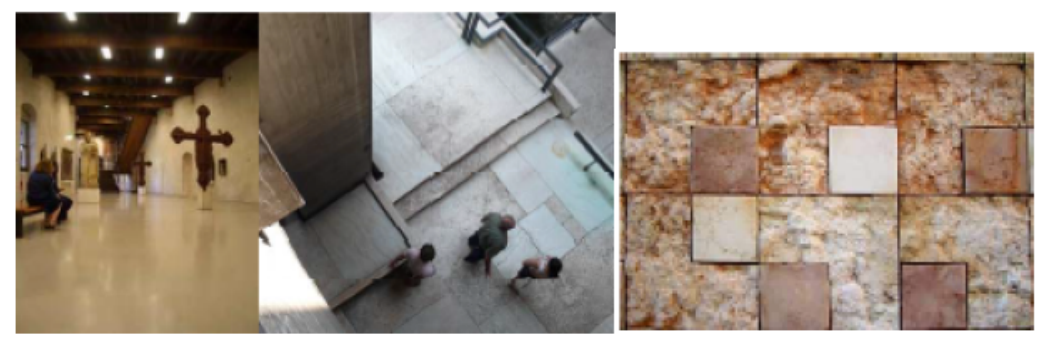

Figure 22: Castelvecchio Details 


\section{KOLUMBA ART MUSEUM \\ PETER ZUMTHOR}

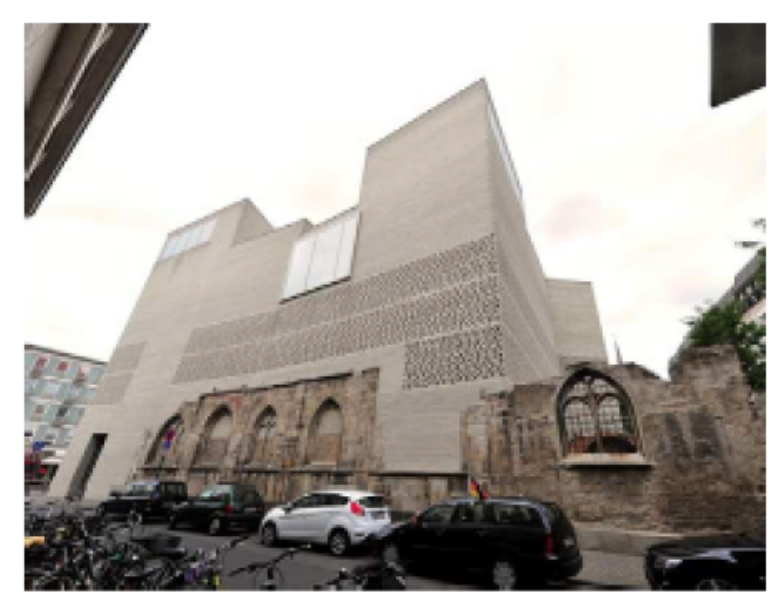

Figure 23: Kolumba Art Museum Exterior

The museum is located in Cologne, Germany and was redesigned by Peter Zumthor. This structure was altered over several historic time periods with different building functions. It was originally a Gothic church that was destroyed in World War II, later it was converted into Roman style architecture with brick and stones. In the 1950s it was used as a chapel for the Madonna of the Ruins. The new enclosure surrounds the existing structure and partially on top of the existing ruins. The new face of the museum is constructed with a light grey brick pattern with perforation of big openings. The brick pattern perforation occurs in areas where diffused light was needed for the interior spaces. The following images illustrate the blending of the new and old together (Zeballos, 2012).

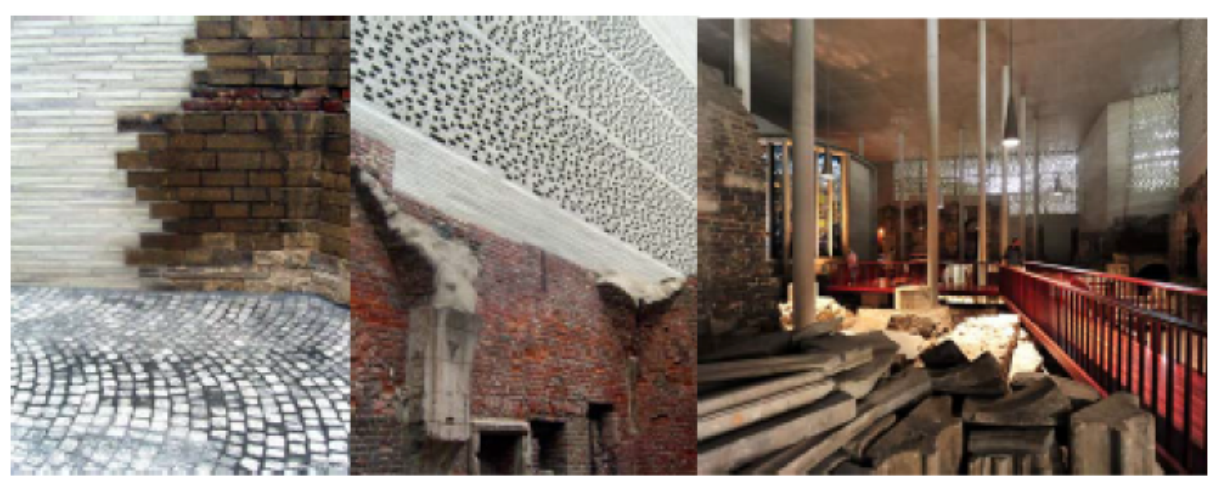

Figure 24: Kolumba Art Museum Details 


\section{PARTICIPATORY DESIGN}

Public spaces are vital to maintain healthy, vibrant communities. These places receive less attention and are funded, designed, constructed and operated differently because of the economic changes over the last few decades. Public spaces are considered 'public' when it is available and accessible to everyone. These spaces act as a catalyst for community development and revitalization (Vander, 2013). Architecture creates stories for places that exist and are continuously transforming. It is vital to be aware of the communities and their built environment that are intertwined as one system. People experience architecture, which in return creates more stories. Adaptive reuse allows these existing structures to be part of the story instead of creating a new story entirely. David Littlefield explains, "Voice of a building emerges slowly, through a fusion (an alchemy) of imagination, metaphor, association, memory, sensory experience, emotional response and hard architectural and historical facts." It is important to listen to the stories, which buildings can tell. Martin Heidegger, a German philosopher, also sees architects as "responders" who listen to the building and creates a new form (Crenshaw, 2013).

Community participation allows the public to have empowerment and to be actively involved in the decision making process. "Citizen participation is a categorical term for citizen power. It is the redistribution of power that enables the have-not citizens, presently excluded from the political and economic processes, to be deliberately 
included in the future" (Arnstein, 1969). Participatory design is a multi-disciplinary approach that can be used in a wide range of industries such as psychology, architecture, planning, history, arts, technology and the sciences. However for the purpose of this thesis it is going to focus on the architectural design process.

Participatory design is a collective process with professional experts and the users working together with an ultimate outcome. The participatory approach allows for users to identify the needs and wants that the professional experts cannot always predict. Therefore, this process provides more insight and assists the professional experts to design what is best for the end users. The approach consists of data collection from the community, it is then tabulated and used as knowledge for the design. The participatory design approach improves a problem or situation, educates the public and provides knowledge.

Based on Littlefield's theory, this design is driven by the participatory approach in order to listen and understand the stories of the existing building. It is important to recognize the existing communities, to understand the architecture and the sense of place that it creates. Due to the continuous battle Fairbank community has faced over the last several years it is significant to incorporate this into the design. As a community Fairbank has a strong voice on their needs and wants in the neighborhood. However, many residents felt unappreciated because of the involuntary closure of their school. Therefore, allowing the community to have 
empowerment over the future development of an existing public space is vital to revitalize the community and create an enriched design (McRorie, 1999).

\section{DATA COLLECTION}

Resident opinions were gathered using three different forms of data collection. The initial form of interaction with the community was more of an informal process, it was done through attending a communityplanning meeting. Attending this community-planning meeting held on November 26, 2013, provided more insight and knowledge on the issue and understanding of the different parties involved in the process. People who attended the meeting were clients, architects, landscape architects, city officials and approximately 75 residents. This method allowed for input from many people in the community and professionals who were involved in the future development of the property. Overall, this form of data collection provided a collective understanding of the community as a whole and what their needs and wants were for the future development of the space. Figure $A$ is the notes taken from the meeting. The community meeting notes concluded the following findings:

- Community members were strongly opposed to high density housing such as townhouses and condominiums

- Residents dislike any multiple story buildings such as residential towers or commercial towers

- Residents are for new development but want the new proposal to match the existing fabric of the neighborhood 
- Factors that they are concerned about are traffic, noise, safety and property value

- Residents were outraged about the school closing

- The school was considered historic and a social place for many people

- Development that they would like to see: continuation of single storey homes, social place for children and park land

The second form of data collection consisted of short surveys that took place after the communityplanning meeting on November 26, 2013 and approximately 35 surveys were completed. This allowed for better understanding of individual community members to identify what they believe is needed in their neighborhood and whether there was an impact in losing their local school. These surveys allowed for a wider range of residents to voice their concerns especially those who may have been uncomfortable speaking up in the meeting. The surveys attached are the questions provided to the community members. Figure $A$ is the tabulation of the results from the survey. The survey findings consist of:

- Briar junior public school was closed because of funding constraints and decline in student enrolment

- Majority of the residents felt a difference in the neighborhood when the school was closed down

- The difference most residents felt was less interaction between residents, less people 
movement, and a decrease in livelihood in the neighborhood

- Majority of the residents felt that Briar Hill was more than just a school, it was a green space, children's play area, and a community hub for interaction

- Majority of the residents were for a new development and would like to see a certain type of building constructed on this property such as single detached houses, semi-detached houses, recreational center, park, community center and cultural center

- Majority of the residents were opposed to: townhouses, condominiums, hotels and commercial spaces
In order to further gain knowledge, door-to-door interviews were conducted as the final means of data collection. This data collection took place over two days on the weekend (December 7 and 8 2013) with participation from 16 residents. The interviews were taped if possible otherwise notes were taken during the interview. These interviews provided feedback from individual community members through series of questions that allowed them to provide more detail through personal stories. The list of questions provided below were the questions asked to the interviewees. Figure $B$ is the tabulation of the results from the interviews. The interview results consist of: 
- About $60 \%$ of residents know the reasons for the school closure are decrease in student enrolment and funding constraints

- Majority of the residents felt the reason was not valid enough to close the school, it could have been used for something else rather than simply demolishing it

- $70 \%$ of the residents had children who were attending or who had attended the school

- More than $80 \%$ felt a difference in the neighborhood when the school closed down mainly in terms of a decrease in livelihood and less people movement

- $50 \%$ of residents attended the meetings regarding the school closure
- Residents felt the neighborhood was missing a recreational or community center and some sort of playground or park land

- All residents are against high density developments like residential and commercial

- There are residents who have lived in this area a few years, and others for decades

\section{SUMMARY}

This design proposal is implemented through the participatory design approach. This approach is defined by community engagement and key findings determined by community meetings, surveys and interviews. The views and opinions of the residents drives the design stages. These different forms of data collection provided a combination of feedback and opinions from the 
residents in order to gain a better understanding. The community engagement findings were the key elements used to determine the program and design of the building. The community wanted the site to be used as public space and the green spaces to be maintained as it was for centuries. The community wanted the converted site to respect the existing fabric of the neighborhood. The program of this building was determined by what the community felt was lacking in their neighborhood and what they thought would be utilized to the fullest capacities. Based on the tabulation of the results, it is clear the residents wanted a community center incorporating particular programmatic areas such as recreational, social spaces, meeting rooms and a library. 


\section{DESIGN PROPOSAL}

\section{DESIGN INTENTIONS}

Architectural palimpsest and transformation is a central design concept that drives this project. Palimpsest provides unique perspectives when responding to an adaptive reuse project. Adaptive reuse is continuing a new phase in an existing building with history and memories. The precedence illustrates the concepts of palimpsest and transformation with the use of materials and details. Even though the approaches are different they all explore and expose the passage of time through their architecture and use of juxaposition. David Chipperfield's approach was recreating the existing structures to the original condition and adding contemporary architecture to show a contrast between the old and the new. Peter Zumthor's approach blends pieces of the old and new materials together, whereas Carlo Scarpa and Sverre Fehn have similar techniques. Carlo Scarpa's approach is juxtaposing the new materials with the existing materials. Sverre Fehn approach is respecting the ruins of the existing structure and inserting modern materials to complete the overall structure. This design incorporates several ideas from the precedent studies.

Fairbank Public School is an exemplary sample of Alvaro Siza's concept of transformation. The school is comprised of elements of construction and destruction, which was recognized as a landmark in the community. Over three time periods, this school has transformed as the neighborhood evolved. Due to public funding the 
school faced a form of destruction to the west portion of the building. With the help of the community and other residents in the surrounding neighborhoods the majority of the school was saved. This thesis can be seen as an additional transformation to the evolving community. The aim of this thesis is to determine how existing schools can be adaptively reused in neighborhoods and continue to act as community hubs for local activities and interaction between people.

1. David Chipperfield - Juxtaposition + Recreating

2. Peter Zumthor - Juxtaposition + Blending

3. Carlo Scarpa - Juxtaposition + Layering

4. Sverre Fehn - Juxtaposition + Inserting 


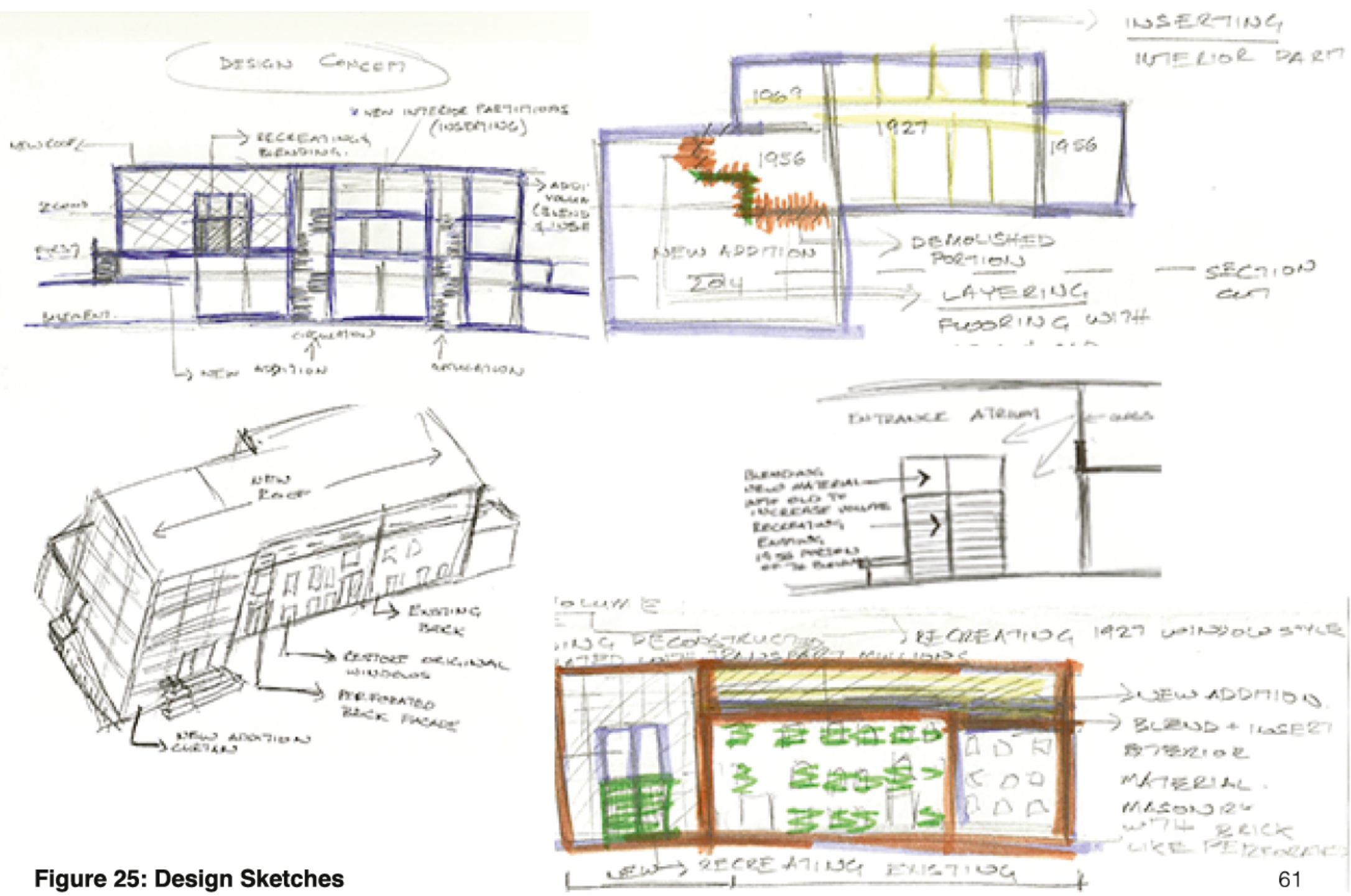




\section{SITE PLAN}

The site plan illustrates the primary entrances into the site, both vehicle and pedestrian, are located on

Dufferin Street. The outdoor exhibition space near the entrance creates a level of visual interest to the pedestrian walking by the site. This space allows residents to showcase their skills and talents constructed in the creation labs. The main entrances into the building are both on Dufferin Street and Briar Hill Avenue. The original building remains with an addition to the southwest part of the existing building that is visible from the main street. There are permeable walkways surrounding the east, north and west side of the building.
The parking lot is located on the southwest corner of the site to avoid traffic impact onto minor Briar Hill Avenue. A children's playground and seating area is located on the lower south side of the site. This is to protect the matured trees and parkland located on this part of the property. There are deciduous trees planted along the north edge of the site to maintain the privacy of the surrounding homes. Located to the right is the baseball field that converts to an ice rink in the winter. The soccer field is northeast of the site. The east part of the site consists of a permeable area with a potential basketball court and playground activities. 


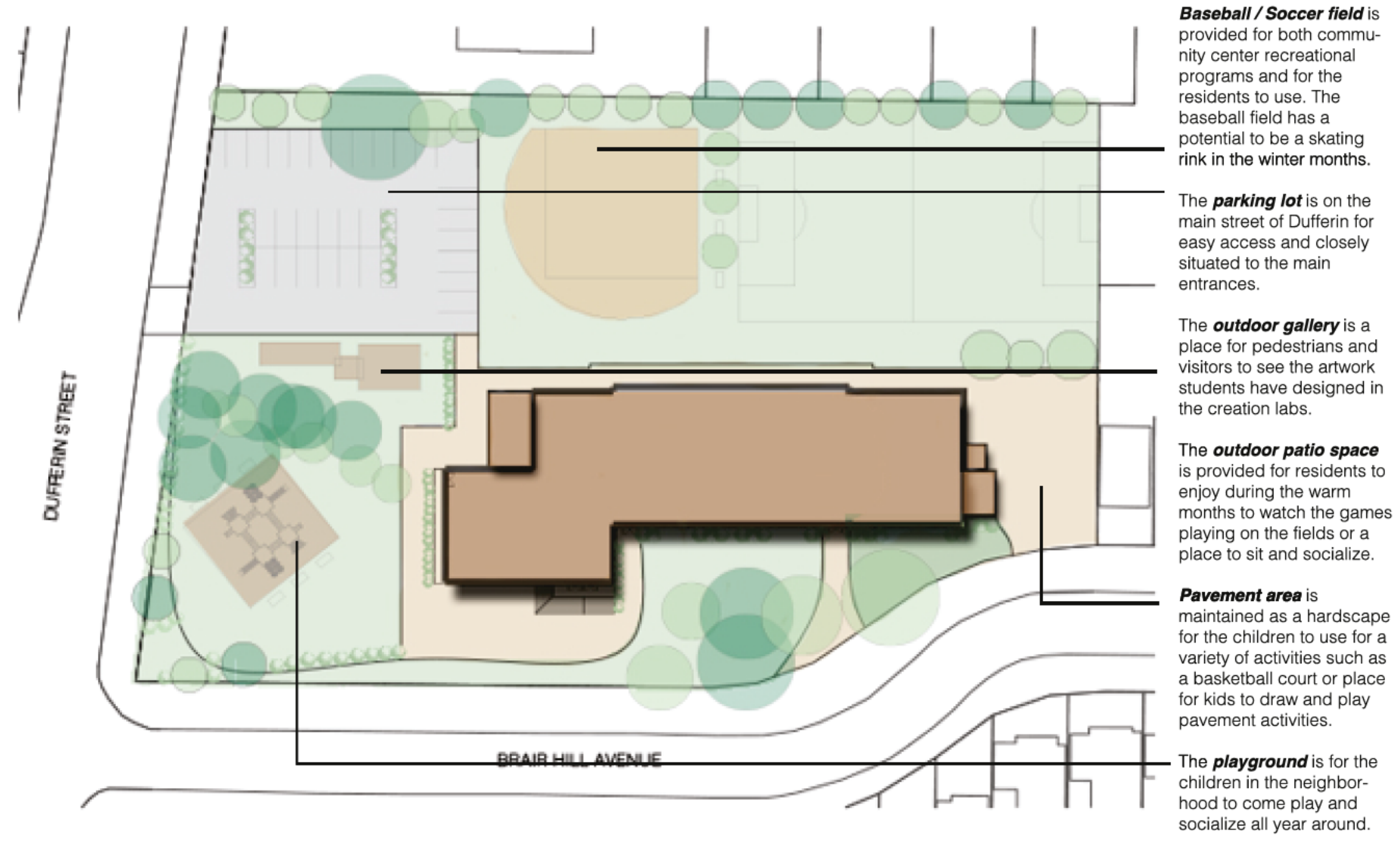

Figure 25: Proposed Site Plan 


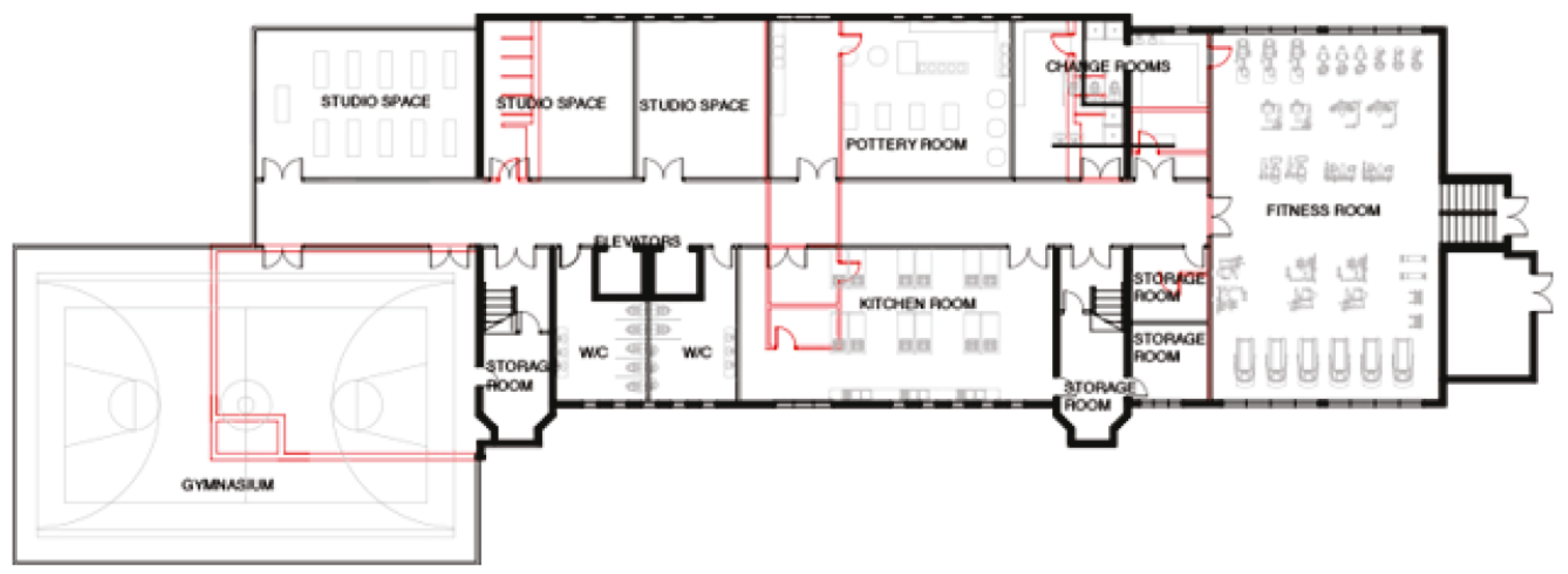

Figure 26: Proposed Basement Floor Plan 


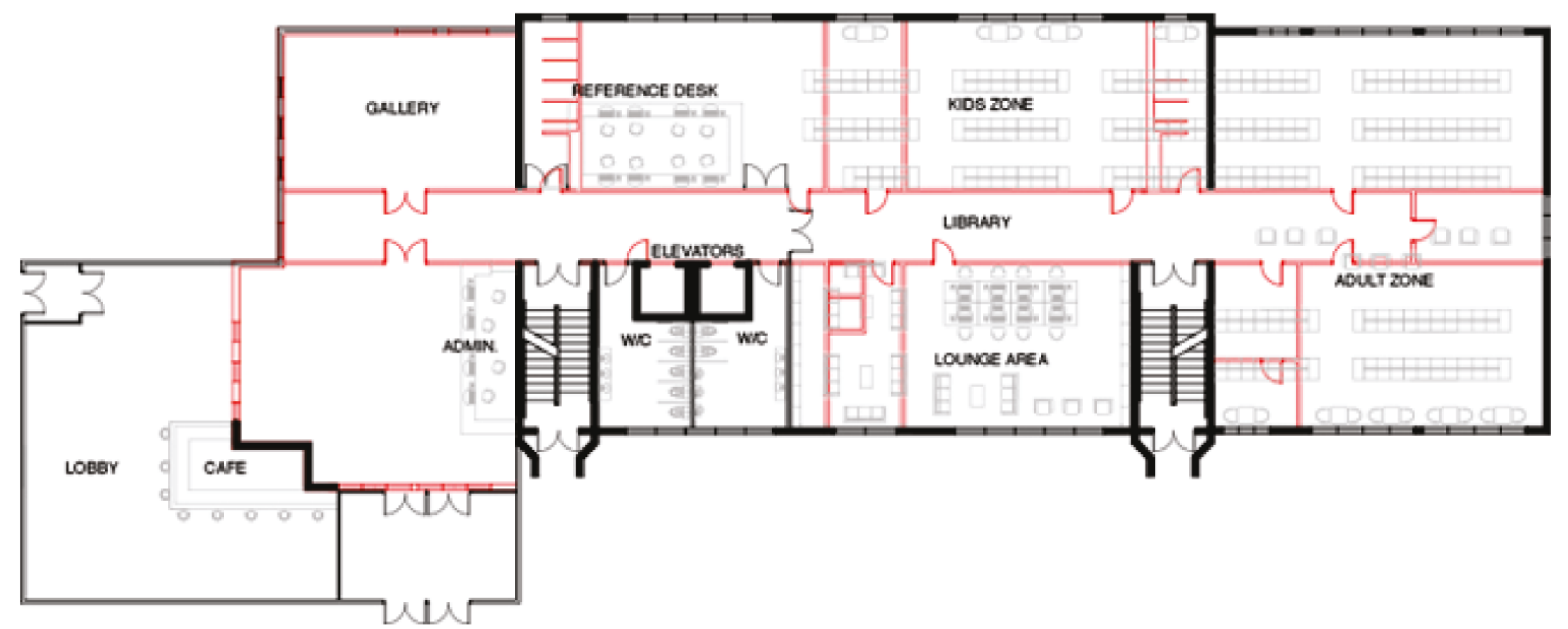

Figure 27: Proposed Main Floor Plan 


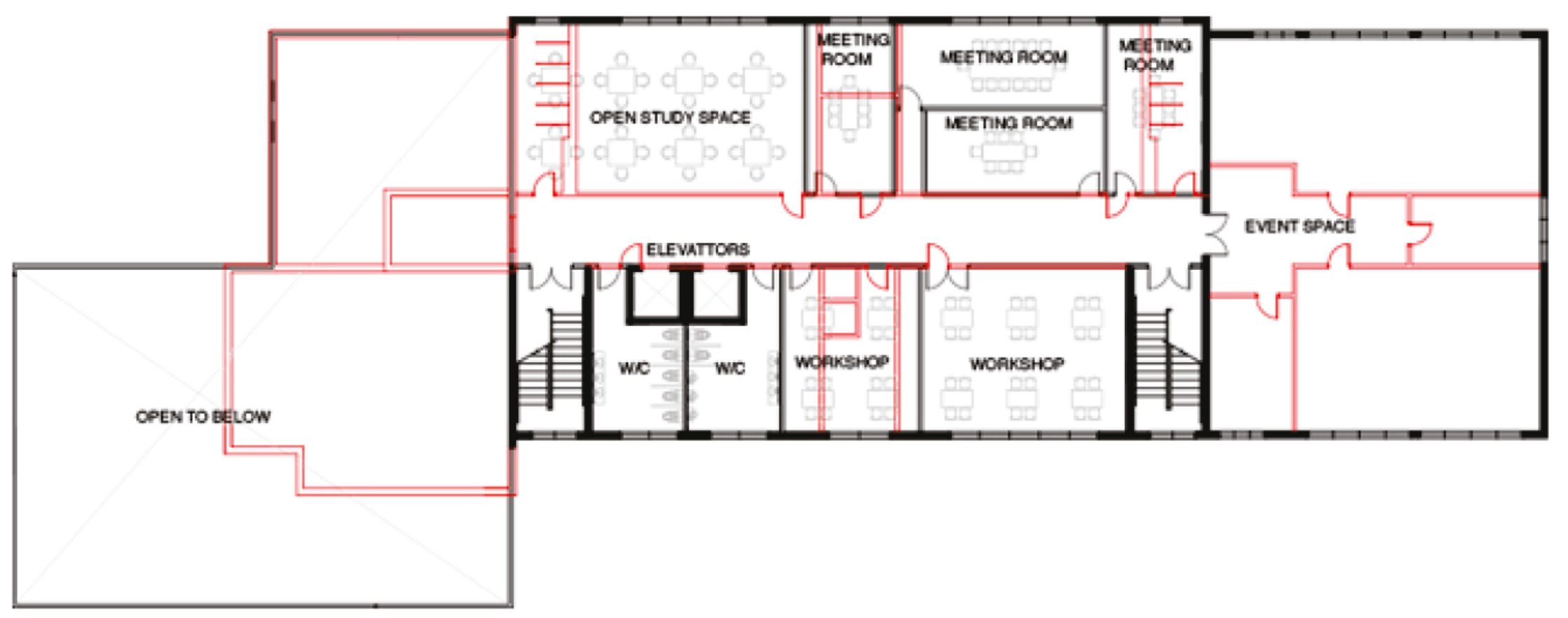

Figure 28: Proposed Second Floor Plan 


\section{EXTERIOR}

This adaptive reuse project consists of additions and interior renovations to the existing structure. The repurposed building has been transformed into a community center and library, with the old and new intertwined. The original plan consisted of several rectangular shaped spaces combined together creating a multilevel elementary school. This is maintained into the new intervention following the simple rectangular shape of the plan and the elevation. The original school was built in 1927, it was a two-storey brick structure surrounded by green space. The front façade of the school consists of two symmetrical highly decorative entrances, one for girls and one for boys. This was a common institutional architectural element in the 1920s, which was preserved and continued to be used as points of access. The overall form of the original school consists of enormous tall windows with detailed craftsmanship surrounding the openings. The ground floor was elevated approximately nine feet above the grade. To respect and honor the main entryways, the grade of the ground floor is preserved. To achieve barrier free access, there are two entrances, one that provides a ramp for wheelchair accessibility and another that has stairs leading to the lobby of the building.

This design consists of both a horizontal and vertical alteration to the existing building. The horizontal extension occurs on the west portion of the existing building, which was partially demolished due to the developers' earlier intentions. The new addition 
incorporates the existing footprint of the 1969 exterior walls that were demolished and highlights portion of the 1956 addition by recreating a piece of the structure. The vertical extension provides a high space for the library and gallery space on the second floor. The existing roof is removed and a new roof is constructed in order to provide a larger volume for the new functions on the second floor. The existing height is not efficient enough for event/exhibition space and a library. Additional height was added to the second floor providing more daylight into the spaces. The material used for the vertical extension is a perforated brick façade that blends with the existing brick façade. The 1927 portion of building is redesigned to use the original 1927 window style to create the past. Therefore, the exterior facades are distinctively designed in order to see the layering of different pieces of the story.

The new addition is a rectilinear glass enclosure that opens up to the community revealing bits and pieces of the past. Also, the glass helps break away from the solid institutional architecture which allows pedestrians walking on the main street to have a glimpse of the interaction and movement in the building. The new transparent element inserts into the old solid building illustrates the connection between the old and the new. The addition consists of a double storey central atrium and green house that vertically connects the first and second floor together. The portion of the building that has been deconstructed is celebrated with transparent glass mullions, which creates an unobstructed view into the 
building. The new inserted element is sensitive to the existing building and context. It respects and plays with the rhythm, proportion, mass and floor alignment of the existing building.

\begin{tabular}{|c|c|c|}
\hline 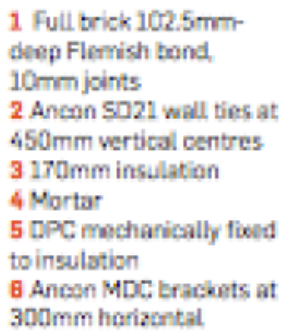 & 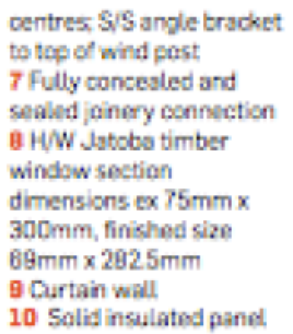 & 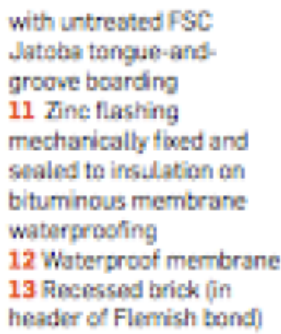 \\
\hline 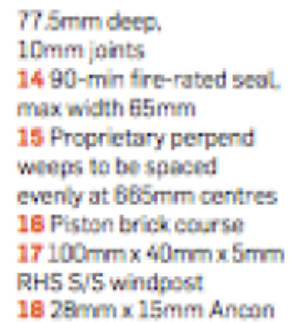 & $\begin{array}{l}\text { chonnel to front of } \\
\text { wind post } \\
19 \text { Aluminium windows } \\
20 \text { Painted } 5 / W \text { frame, sill } \\
\text { and hesdboard to scoustic } \\
\text { Ining to window surnund } \\
21 \text { Solid bricks, } 215 \mathrm{~mm} \times \\
102.5 \mathrm{~mm} \times 65 \mathrm{~mm} \\
\text { without frogs, perforste } \\
\text { Flemish bend } \\
22 \text { Brick window sall }\end{array}$ & 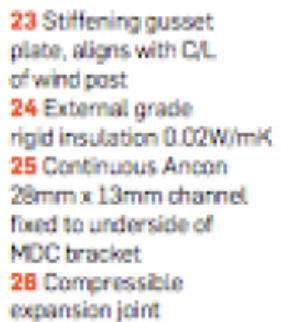 \\
\hline
\end{tabular}
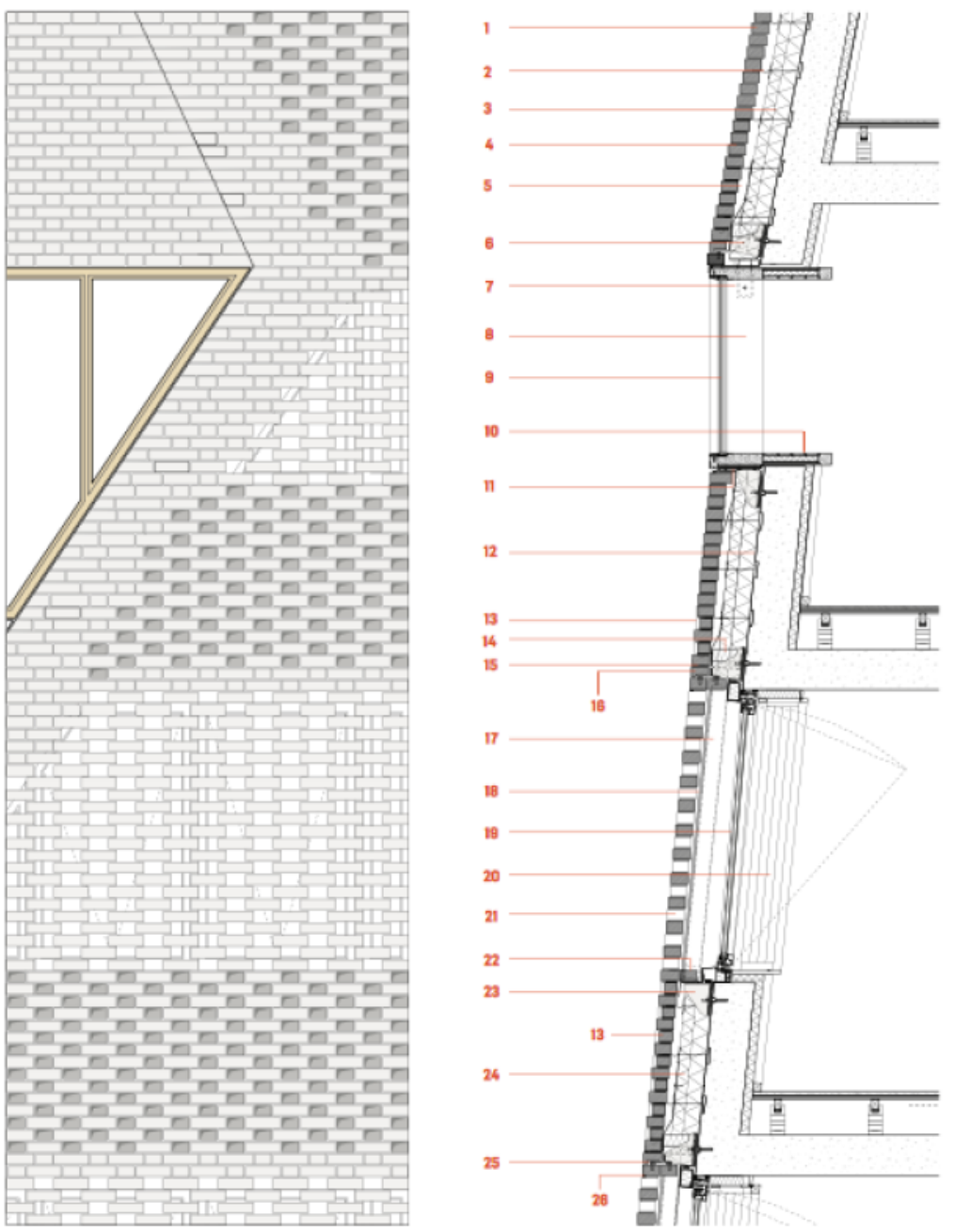

Figure 27: Perforated Brick Wall Detail 


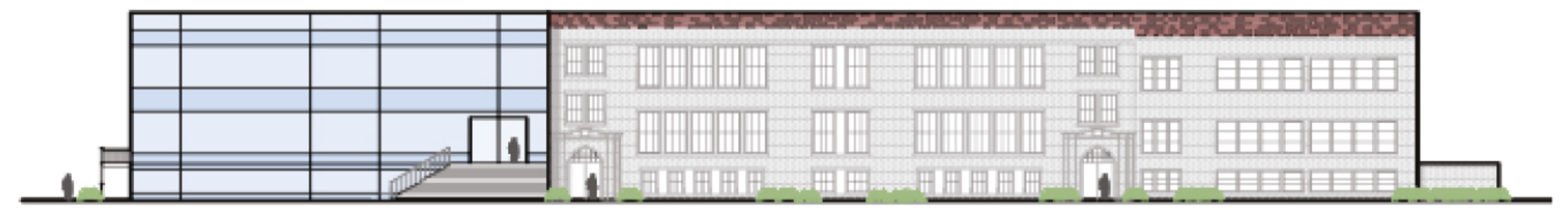

South Elevation

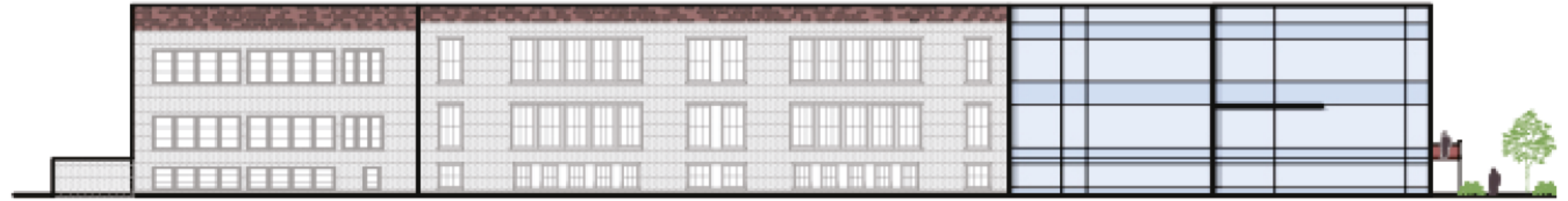

North Elevation

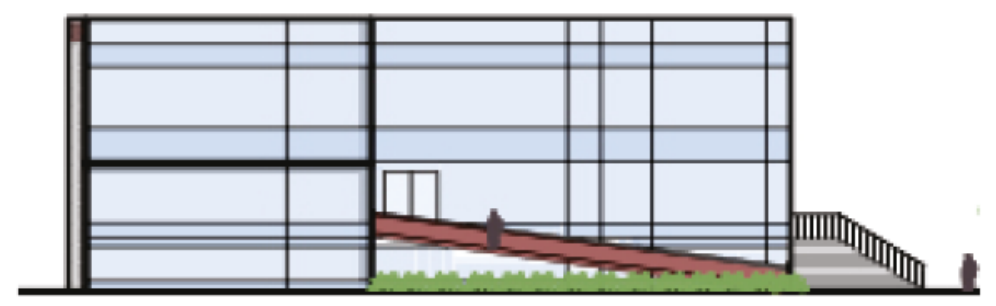

West Elevation

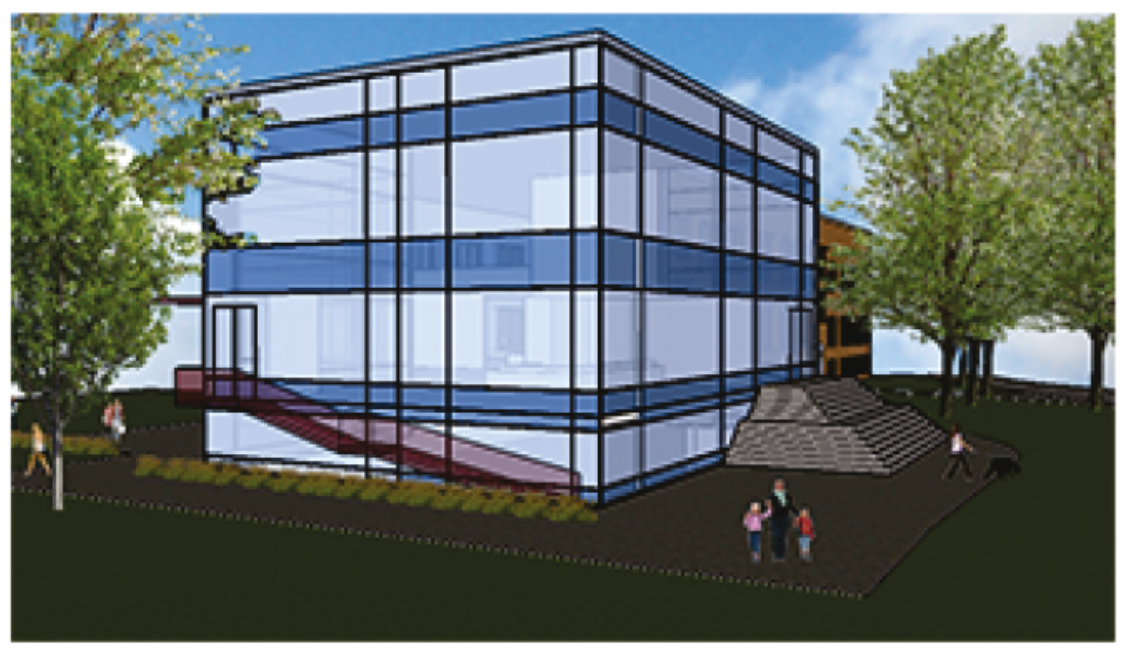

Figure 28: Exterior Elevations \& Rendering 


\section{INTERIOR}

The exterior of the adaptive reuse building consciously focuses on the juxtaposition of the old and new pieces. The lobby is exposed to the existing exterior brick and the plaque of the school's name is evident to the visitor in the lobby. The central element in the lobby of the building is a corner piece of the existing structure that was recreated from the demolished portion of the structure that serves as the focal point. To increase the height of the recreated focal point new material is blended into the old. The lobby floors illustrate the old and new portion of the building by differentiating the material and texture of tiling. The interior consists of exposed exterior red brick walls with the insertion of tempered glass. The intent is to provide visibility to the public, the users and the staff with a clear connection to the different spaces throughout the building. The interior aesthetic reinforces the different program spaces through the people movement by the use of glass partitions. The interior partitions vary from opaque, translucent to transparent based on the use of the room. This is achieved by the use of tempered glass. The overall design intent is to communicate the culture of the community center to the users, the staff and the public as a whole. 

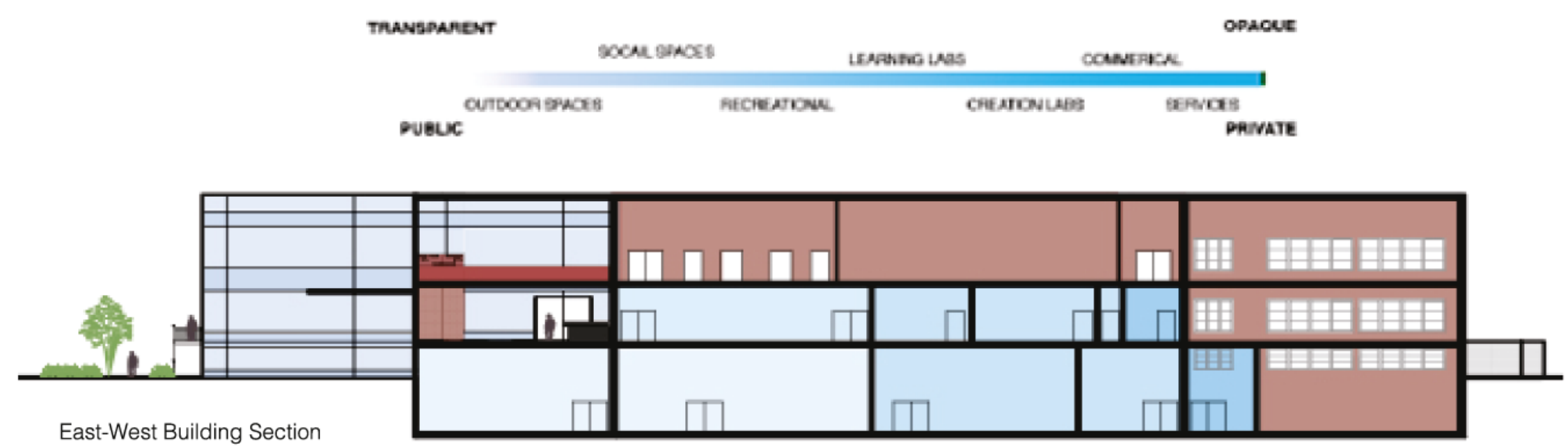

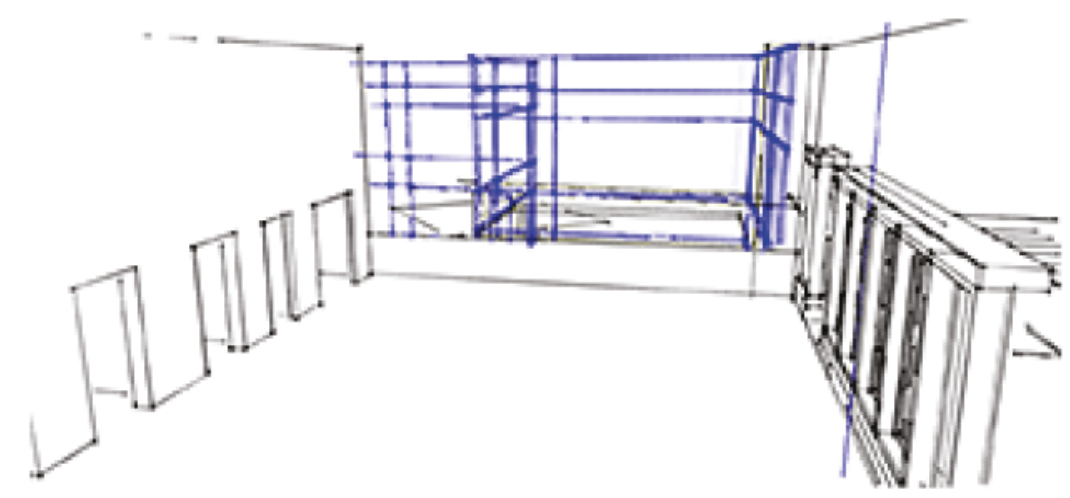

Interior Second Floor Balcony

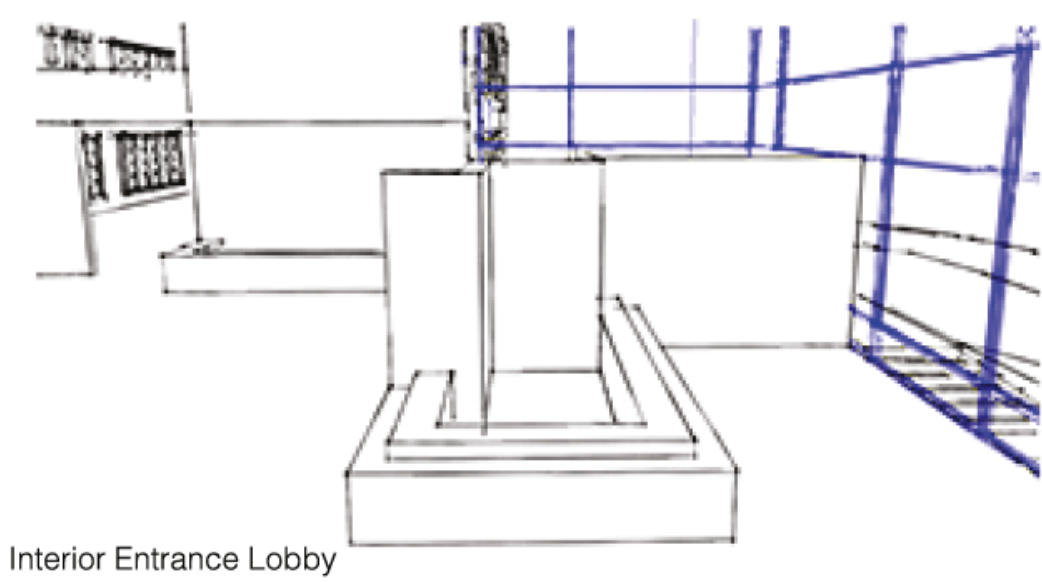

72

Figure 29: Proposed Section \& Interior Renderings 


\section{CONCLUSION}

Architecture and community both create a sense

of place. Communities transform over time due to the economic and social needs of the residents. As a result, it is vital to understand how communities transform over time. Architecture should be transforming in order to respond to the surrounding context.

To understand the people and their communities and to challenge the conventional strategies of design, an innovative approach such as participatory design can be used. This approach can drive the design, function and form. These different forms of data collection provide a combination of feedback and opinions from the residents in order to gain a better understanding.
Public spaces are vital to maintain healthy vibrant communities. Public spaces act as a catalyst for community development and revitalization. Schools are not only places of learning; they are vital anchors that act as community hubs for local activities, interaction, communication and togetherness. Losing your local school is like losing the heart of the community that provides liveliness to your neighborhood, this was the case with the Fairbank Community.

In the Fairbank community schools were endangered because of the change in age groups and population size. Fairbank is considered a historic neighborhood in the City of Toronto. One of the historic landmarks in the Fairbank neighborhood is the Briar Hill Junior Public School. The school was a landmark and 
community hub for the residents of this area. Many residents were affected by the absence of this school when it was deemed 'surplus' and closed.

In some situations, it is financially sustainable to close down existing schools and build a new school in its place. In other situations, it is more effective to close down two existing schools and built one larger school. The current solutions for school closures are renovations, adaptive reuse or demolitions. However, many schools are easily demolished and the other two options are not frequently used.

Fairbank Public School is an exemplary sample of Alvaro Siza's concept of transformation. The school comprises elements of construction and destruction, which was recognized as a landmark in the community. Over three time periods, this school has transformed as the neighborhood evolved. Due to public funding the school faced a form of destruction to the west portion of the building, with the help of the community and other residents in the surrounding neighborhoods the majority of the school was saved. This thesis can be seen as an additional transformation to the evolving community. Architectural palimpsest and transformation is a central design concept that drives this project.

Palimpsest provides unique perspectives when responding to an adaptive reuse project. The design is developed through precedence studies with five methods, juxtaposition, recreating, inserting, layering and blending. Even though the approaches are different they all explore 
and expose the passage of time through architecture and the use of materials and details.

This design is derived from responding to the existing community and context, by preserving the existing structure and maintaining its functionality as a public building. The site will be reconnected to the community, allowing residents, visitors and staff to remember the past and experience its new purpose. The goal of this thesis is provide an alternative solution to the simple conventional method of demolition and new construction and to reconsider the connection between adaptive reuse and participatory design. The architectural strategies that inspired this design are just one of many examples. The aim of this thesis is to think beyond the ideology of old and new structures, instead think about the transformation of structures as: in with the old and out with the new. 


\section{EPILOGUE}

Participatory design approach reinforces a greater connection between the community and the site itself. Community engagement provided an in-depth analysis of the past, present and the future of the site and aided in the heritage and design process. Due to the minimum funding the city provides to community centers and more so for this region, the residents will aim for a selfsufficient community centre. Further investigation is required to explore the diverse sources of funding for the community centre. The design incorporates several conceptual strategies to provide revenue to the community centre with commercial rentable spaces, recreational and creation lab classes. In order to provide additional revenue to the city the conceptual diagram below illustrates the possibility of how a portion of the sports field can be proposed as housing. By preserving the historic school and utilizing a portion of the site this can minimize the tension between the developer and community members. 


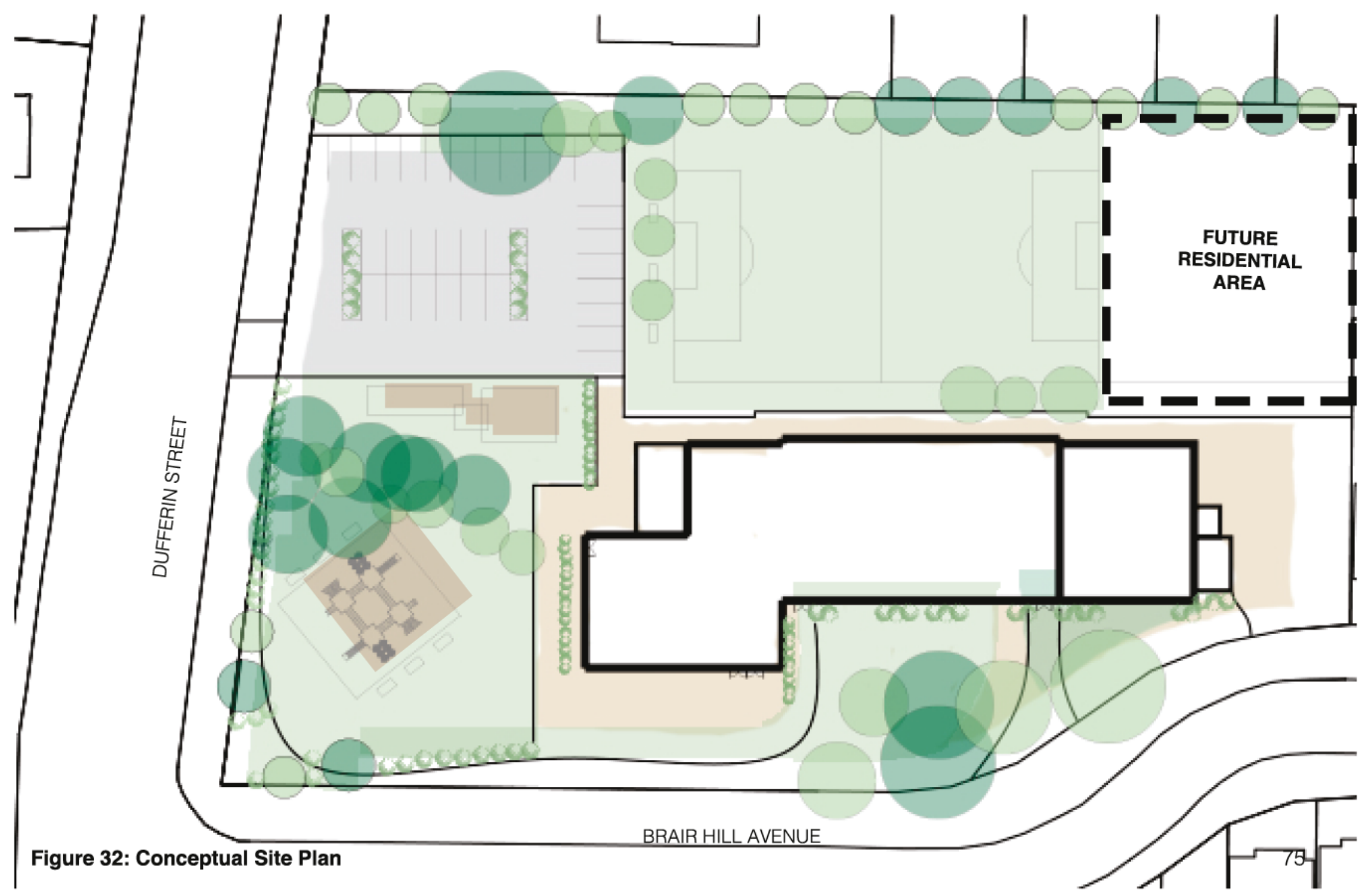




\section{REFERENCE}

Archer, L. A. (2009, April 20). Save our (heritage) schools: The adaptive re-use of our dying institutional buildings. SpacingToronto, Retrieved from (website). April 222014.

Arch Daily. (2011, April 28). Neues Museum / David Chipperfield Architects in collaboration with Julian Harrap. Retrieved from http://www.archdaily.com/127936/neues-museum-david-chipperfield-architects-in-collaboration-with-julian-harrap/. March 162014.

Arch Daily. (2011, May 9). The Bloor/Gladstone Library / RDH Architects. Retrieved from http://www.archdaily.com/133796/the-bloorgladstone-library-rdh-architects/. March 162014.

Arch Daily. (2011, March 11). Brooklin Community Centre And Library / Perkins + Will. Retrieved from http://www.archdaily.com/117462/brooklin-community-centre-and-library-perkins-will/. March 162014.

Artspace (2012). Bell school arts campus new life for a tremé neighborhood center. Retrieved from http://www.artspace.org/our-places/bell-school-arts-campus. April 132014

Billespartners. (2013). Artspace nola. Retrieved from http://billespartners.com/pages/portfolio/default.aspx?catid=3\&projectid=146. April 132014.

City of Toronto. (n.d.). 1100 Briar Hill Avenue Zoning By-law Amendment Application - 13221087 NNY 15 OZ. Retrived from http://www1.toronto.ca/wps/portal/contentonly?vgnextoid=9683d2dd55273410VgnVCM10000071d60f89RCRD\&vgnextch annel=490452cc66061410VgnVCM10000071d60f89RCRD. February 32014.

(Christiansen, Anette Broteng). (2013, October 10). Sverre Fehn Built Norway's Architectural Reputation. Retrived from http://thornews.com/2013/10/10/sverre-fehn-built-norways-architectural-reputation/. March 142014.

Community use of schools. People for Education. The Annual Report on Ontario's Public Schools 2007. 
Crenshaw, Emma Elizabeth. "Transforming Together: Reconsidering Adpative Reuse." M.Arch. Thesis. University of Maryland, 2013. Projects. Web. 16 Mar. 2014.

Dyson, D. D. (2010). Double jeopardy for poorer schools in tdsb school closing process. Belonging community, Retrieved from http://belongingcommunity.wordpress.com/?s=Double Jeopardy for Poorer Schools

In TDSB School Closing Process. February 72014.

David Chipperfield Architects. (n.d.). Neues Museum, Museum Island Berlin, 1997-2009. David Chipperfield Architects. Retrieved from http://www.davidchipperfield.co.uk/project/neues_museum. March 82014.

Etherington, Rose. (2009, March 4). Neues Museum by David Chipperfield Architects and Julian Harrap Architects. de zeen magazine. Retrieved from http://www.dezeen.com/2009/03/04/neues-museum-by-david-chipperfield-architects-andjulian-harrap-architects/. February 242014.

Fredua-Kwarteng, E. F. (2005). School closures in Ontario: Who has the final say?. Canadian Journal of Educational Administration and Policy, (46), Retrieved from http://www.umanitoba.ca/publications/cjeap/. April 62014.

Kohn, L. (2011). Artscape to repurpose historic shaw street school into 75,000 square foot multi-dimensional centre. Retrieved from http://torontoartscape.org/news/artscape-repurpose-historic-shaw-street-school-75000-square-foot-multidimensional-centre. April 222014.

McMenamins Inc. (2013). History still a community center. Retrieved from http://www.mcmenamins.com/104-kennedyschool-history. March 32014.

McNulty, I. (2012, October 30). Community impact series: Artspace. Retrieved from http://wwno.org/post/community-impactseries-artspace. April 132014.

McRorie, Karen. "The Playground Project: A Case Study in Participatory Design”. MA Thesis. Library and Archives Canada, 1999. Web. 16 Mar. 2014. 
(Noppen, Luc). “The Architecture of Old Quebec, or The History of a Palimpsest”. Material Culture Review 50 Fall (1999). Electronic Text Centre Journals. 20 Mar 2014.

Ontario's Small Schools. People for Education. 2005.

O’Reilly, D. O. (2013). Harry stinson goes back to school. Thestar. Retrieved from

http://www.stinsonschool.com/articles/Torstar_Harry Goes Back to School.pdf. March 32014

Peets, C. P. (2013). Goodes hall expansion-queen's school of business. Retrieved from http://dtah.com/wpcontent/uploads/2013/05/2013-04_Queens-Goodes-Hall_Award1.pdf. February 172014.

Penlington, Hannah. "Dirty Laundry: The adaptive reuse of an existing building". M.Arch. Thesis. Unitec Institute of Technology, 2010. Architeicture Dissertations and Theses. Web. 16 Mar. 2014.

Queen's University. (2012). Goodes hall. Retrieved from http://business.queensu.ca/about_us/goodes_hall.php. February 17 2014.

RASANU, S. R. (2012). The acquisition and redevelopment of surplus schools in toronto, ontario: An assessment of the city of toronto's school lands property acquisition policy. QSpace, Retrieved from

http://qspace.library.queensu.ca/bitstream/1974/7351/1/Master's Report Final - August 2012 (Simona Rasanu).pdf. March 22014.

Rinaldi, Jérémy. (n.d.). Fehn, Sverre: Hedmark Museum, Hamar, Norway. Retrieved from http://theredlist.com/wiki-2-19879-606-619-view-fehn-sverre-2-profile-fehn-sverrehedmark-museum-hamar-norway.html

School Closings in Ontario. People for Education's report on accommodation reviews and school closings 2009.

Stinson School Inc. (2013, December 6). Stinson school lofts. Retrieved from http://stinsonschool.com/Construction_Progress.html. March 32014 
Sota Construction Services, Inc. (n.d.). South hills retirement residence. Retrieved from http://www.sotaconstruction.com/project_details.asp?id=37. March 3 2014,

Teeple architects leads transformation of shaw street school into artscape youngplace. (2013, November 25).Canadian Architect, Retrieved from http://www.canadianarchitect.com/news/teeple-architects-leads-transformation-of-shaw-streetschool-into-artscape-youngplace/1002751775/?\&er=NA. April 132014.

Tielman, M. (2012). Homeschool: Living in converted school buildings. Retrieved from http://www.designsponge.com/2012/09/homeschool-living-in-converted-school-buildings.html. March 32014.

Toole, J. S. T. (2012). You live in a school?! adaptive reuse in pittsburgh. And Function, Retrieved from w w w . s m i m a g a $\mathrm{z}$ i $\mathrm{n}$ e.c o m. February 72014.

TDSB. (2010). Brock junior public school. Retrieved from http://www.tdsb.on.ca/profiles/5207.pdf. February 172014.

Vander Klok, Jordan. "Participatory Design and Public Space: Catalysts for Community Development: A Case Study in Barrio Grenada". MLA Thesis. University of Guelph, 2013. Theses \& Dissertations. Web. 16 Mar. 2014.

Wiebe, C. W., \& Quinn, C. Q. (2010). Are canada's historic schools. H -E RITAGE, XI I I(3/4), 20-29. Retrieved from http://www.heritagecanada.org/sites/heritagecanada.org/files/magazines/2010/issue3-4/Heritage3+4.2010-Feature2E.pdf. March 22014.

Wilson, Corey Andrew. "Adaptive Reuse of Industrial Buildings in Toronto, Ontario. Evaluating Criteria for Determining Building Selection.” M.PL. Thesis. Queen's University, 2010. Queen's Theses \& Dissertations. Web. 16 Mar. 2014.

Yu , A. (2013, July 2). Artscape revitalizes heritage shaw street school in queen west. Retrieved from

http://urbantoronto.ca/news/2013/07/artscape-revitalizes-heritage-shaw-street-school-queen-west. April 222014.

Zeballos, Carlos. (2012, April 24). Peter Zumthor: Kolumba Museum, Cologne. My Architectural Moleskine. Retrieved from http://architecturalmoleskine.blogspot.ca/2012/04/peter-zumthor-kolumba-museum-cologne.html. February 12 2014. 
Canada's Capital University
Carleton University Research Office

Research Ethics Board

1325 Dunton Tower

1125 Colonel By Drive

Ottawa, ON K1S 5B6 Canada

Tel: $613-520-2517$

ethics@carleton.ca

\section{Ethics Clearance Form}

This is to certify that the Carleton University Research Ethics Board has examined the application for ethical clearance. The REB found the research project to meet appropriate ethical standards as outlined in the Tri-Council Policy Statement: Ethical Conduct for Research Involving Humans, $2^{\text {nd }}$ edition and, the Carleton University Policies and Procedures for the Ethical Conduct of Research.

\section{$X$ New clearance}

$\square$ Renewal of original clearance

Original date of clearance:

Date of clearance

Researcher

Department

Supervisor

Project number

Title of project
24 December 2013

Ajantha Kumarasingam, Master's student

Azrieli School of Architecture \& Urbanism

Prof. Mariana Esponda, Azrieli School of Architecture \& Urbanism 100891

In with the old and out with the new: Adaptive re-use of our dying schools

\section{Clearance expires: 31 May 2014}

\section{All researchers are governed by the following conditions:}

Annual Status Report: You are required to submit an Annual Status Report to either renew clearance or close the file. Failure to submit the Annual Status Report will result in the immediate suspension of the project. Funded projects will have accounts suspended until the report is submitted and approved.

Changes to the project: Any changes to the project must be submitted to the Carleton University Research Ethics Board for approval. All changes must be approved prior to the continuance of the research.

Adverse events: Should any participant suffer adversely from their participation in the project you are required to report the matter to the Carleton University Research Ethics Board. You must submit a written record of the event and indicate what steps you have taken to resolve the situation.

Suspension or termination of clearance: Failure to conduct the research in accordance with the principles of the Tri-Council Policy Statement: Ethical Conduct for Research Involving Humans, $2^{\text {nd }}$ edition and the Carleton University Policies and Procedures for the Ethical Conduct of Research may result in the suspension or termination of the research project.

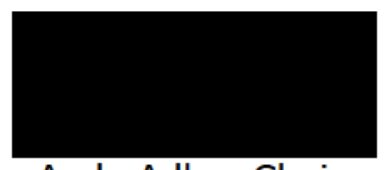

Andy Adler, Chair

Carleton University Research Ethics Board

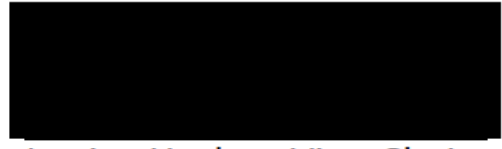

Louise Heslop, Vice-Chair

Carleton University Research Ethics Board 
Purpose of study: A study on adaptive reuse of our dying schools. This study aims to understand the impact of Briar Hill Junior Public School closing down on the community and the alternative use for the existing property

\section{Please circle or underline your answer. Can be more than one answer per question.}

1) Do you know why Briar Junior Public School was closed?

Funding constraints

Aging school building
Decline in student enrolment

Development pressures

2) Did you feel a difference in the neighourbood when the school was closed down?

Yes

No

3) If yes to question 2, what difference do you feel?

Decline in noise

Less interaction between residents

A decrease in livelihood in the neighborhood
A decrease in traffic

Less people movement

4) Did you think Briar Hill was more than just a school?

Yes

No

5) If yes to question 4, what did the school mean to you?

Community hub for interaction

Held social meetings and events
Green spaces

Children play area

6) How many community meetings did you attend when the topic of redevelopment was open for decision?

None $\quad 1-2 \quad 3$ or more

7) What do you think is missing in your community that you would like to see built on this property?

Alternative School Facility (Adult School, Trade School, College)

Community Center \& Cultural Center

Recreational Center \& Park

Single Detach Houses \& Semi Detach Houses

Retail Stores \& Grocery store \& Restaurants

8) What do you not want to see built on this property?

Alternative School Facility (Adult School, Trade School, College)

Community Center \& Cultural Center

Recreational Center \& Park

Single Detach Houses \& Semi Detach Houses

Retail Stores \& Grocery store \& Restaurants
Library

Hotel or Bed Breakfast

Daycare \& Preschool Facility

Townhouses \& condominium

Commercial Spaces (Offices)

Thank you for your time. 


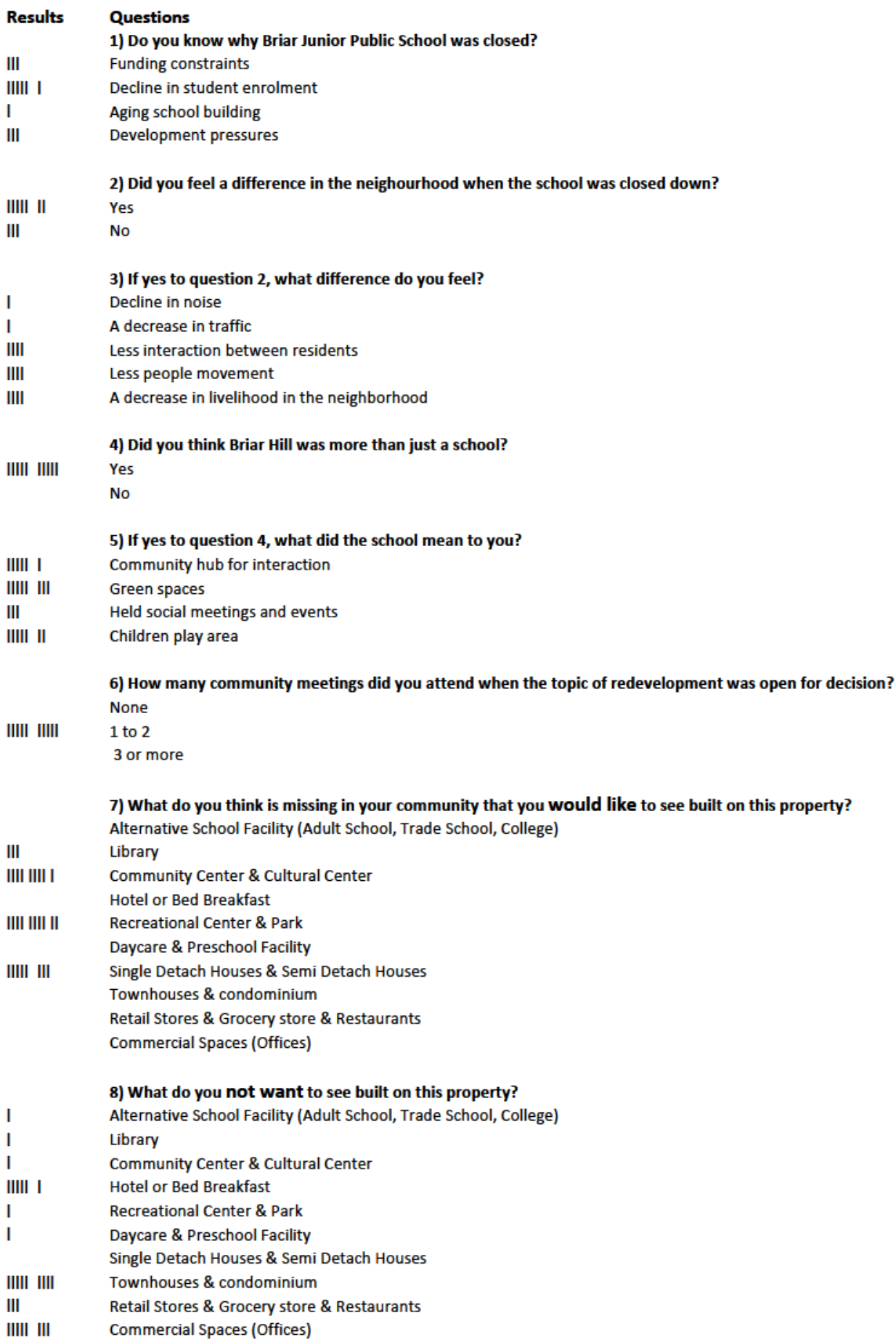

7) What do you think is missing in your community that you would like to see built on this property?

III Library

IIII IIII I Community Center \& Cultural Center

Hotel or Bed Breakfast

IIII IIII II Recreational Center \& Park

Daycare \& Preschool Facility

IIIII III Single Detach Houses \& Semi Detach Houses

Townhouses \& condominium

Retail Stores \& Grocery store \& Restaurants

Commercial Spaces (Offices)

8) What do you not want to see built on this property?

I Alternative School Facility (Adult School, Trade School, College)

I Library

I Community Center \& Cultural Center

IIIII I Hotel or Bed Breakfast

I Recreational Center \& Park

I Daycare \& Preschool Facility

Single Detach Houses \& Semi Detach Houses

IIIII IIII Townhouses \& condominium

III Retail Stores \& Grocery store \& Restaurants

IIIII III Commercial Spaces (Offices)

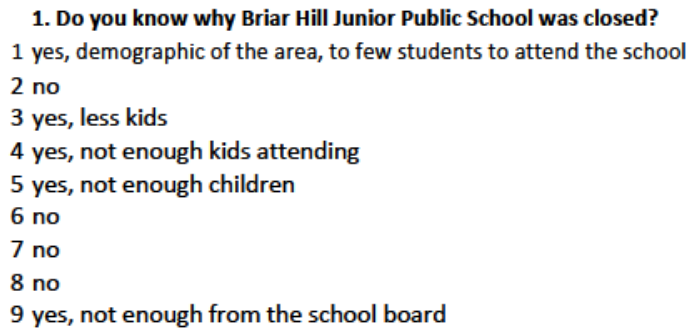


10 yes, declining number of children

11 not sure

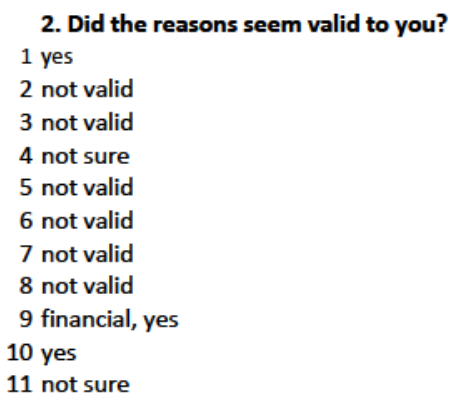

11 not sure

\section{Do you have any kids that attended or are attending this school?}

1 none

2 one child was attending the school

3 one attended this school

4 none

5 two children attended the school

6 one child was suppose to attend this school

7 two children attended this in the past

8 none

9 one child attended the school

10 one was attending the school

11 none

4. Did you think Briar Hill was more than just a school, did you feel the difference in the neighborhood? 1 no change

2 yes, atmoshphere changed, no kids around, closed, quiet

3 yes, less people

4 yes, like children around the neighborhood

5 yes, community movement

6 yes

7 yes, miss the livelihood of the neighborhood without the children, less people movement

8 yes, in the mornings the livelihood of the children

9 not really, maybe the busyness of the children

10 yes, the livelihood of children

11 not really, less people movement

\section{Did you attend the meetings that were held when this topic was open for decision?}

1 no

2 no

3 yes

4 yes

5 no

6 no

7 yes

8 yes

9 no

10 yes

11 no

6. What do you think is missing in your community that you would like to see built on this property? 1 park land, type of housing less density

2 park

3 community center

4 something for children

5 place for children to play and learn

6 public interaction place, park

7 playground, park

8 single homes, semi-detached homes

9 community involvement place

10 recreational center

11 park 
7. What would you like not see built on this property?

1 no high density housing

2 no towers or townhouses

3 not townhouses \& condominium

4 no townhouses

5 no to high dense residential

6 not residential complex

7 not residential towers

8 not townhouses \& condominium

9 not towers residential or commercial

10 no residential

11 no commercial

8. How long have you been living in this neighborhood?

1 over 5 years

2 over 10 years

3 over 7 years

4 over 35 years

5 over 20 years

6 more than year

7 over 2 years

8 over 4 years

9 more than 5 years

10 over 4 years

11 over 5 years

\section{Additional Comments}

1 none

2 townhouses or other development will change the demographics and the community as a whole

3 none

4 don't want new development to increase traffic

5 none

6 standard of living is reduced with new townhouses proposed, traffic will increase, crime will go up

7 open to new development but needs to mix the existing neighborhood

8 the meetings to keep the school open was pointless and the city didn't listen to the community opinions

9 new development shouldn't change the demographic of the type of people living here

10 the closed to fast, should have kept it opened

11 none 


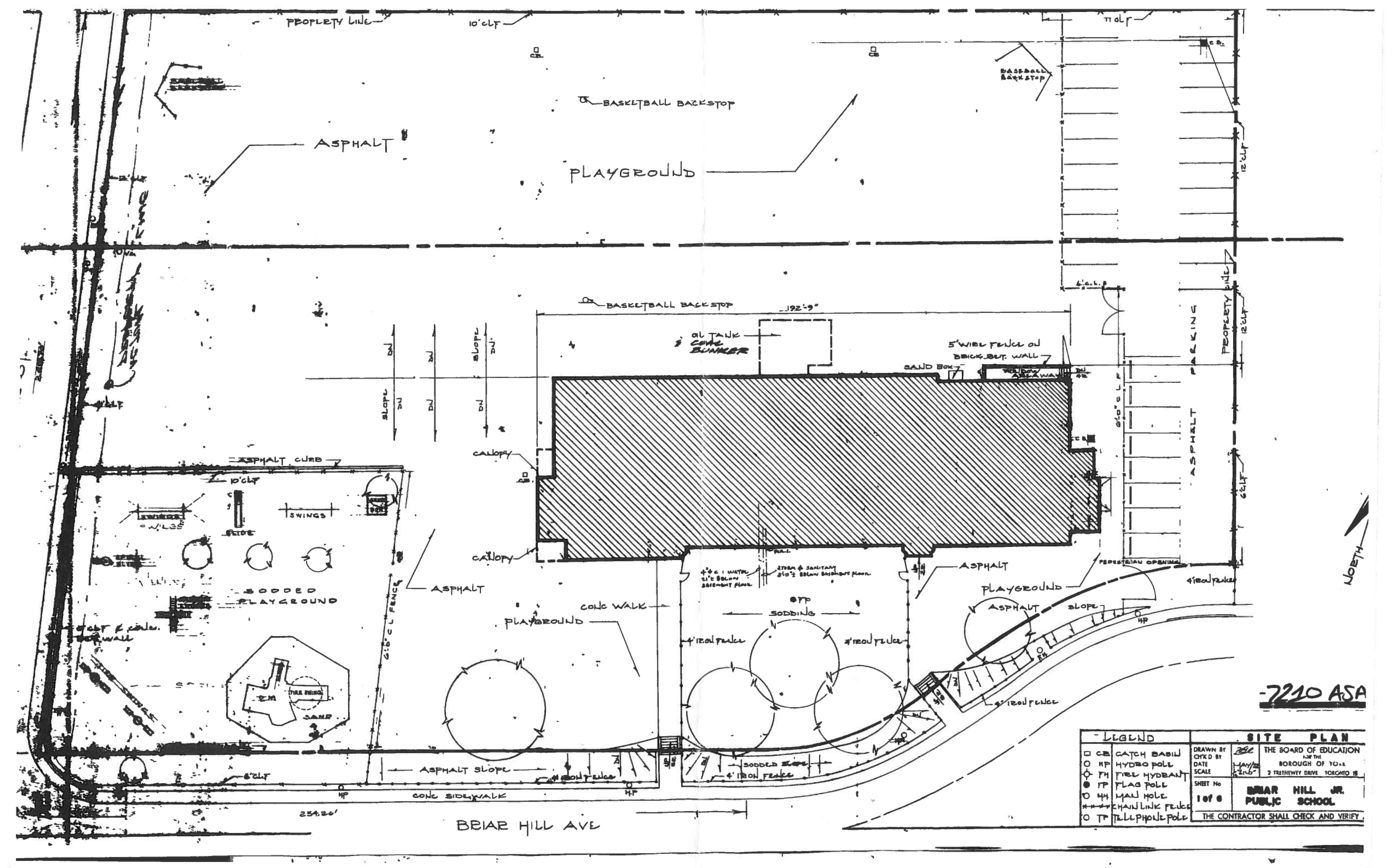




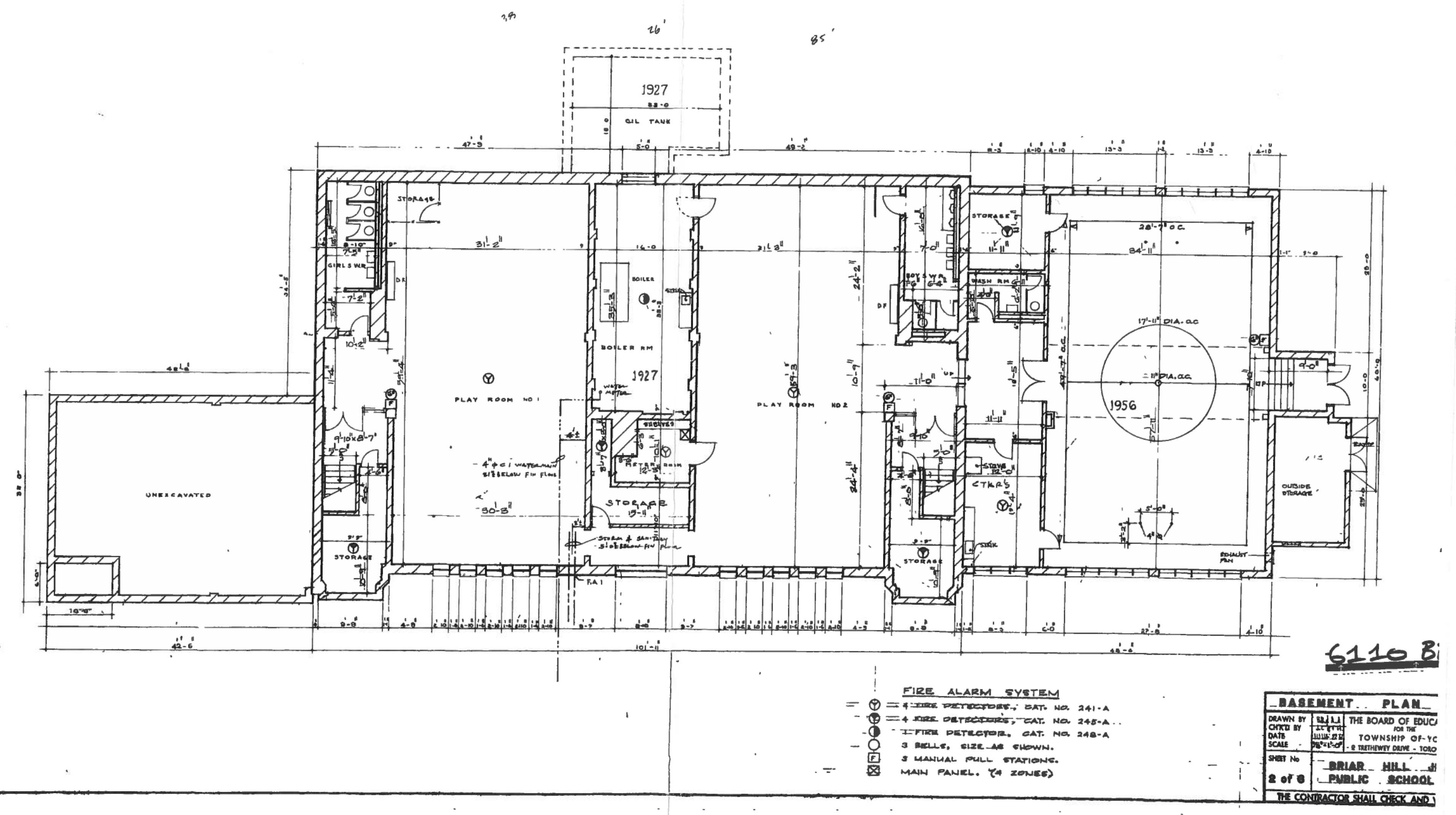




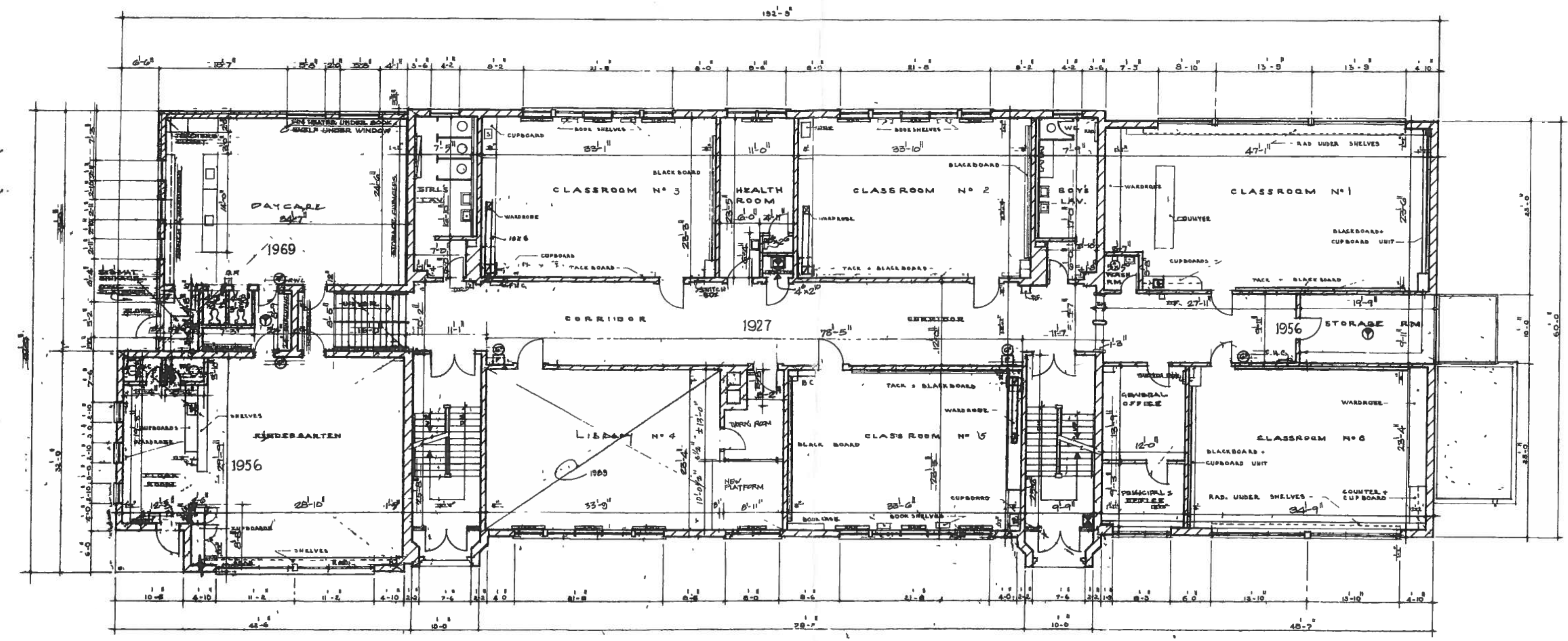

611031

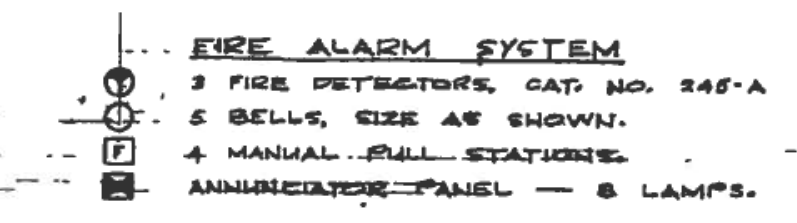




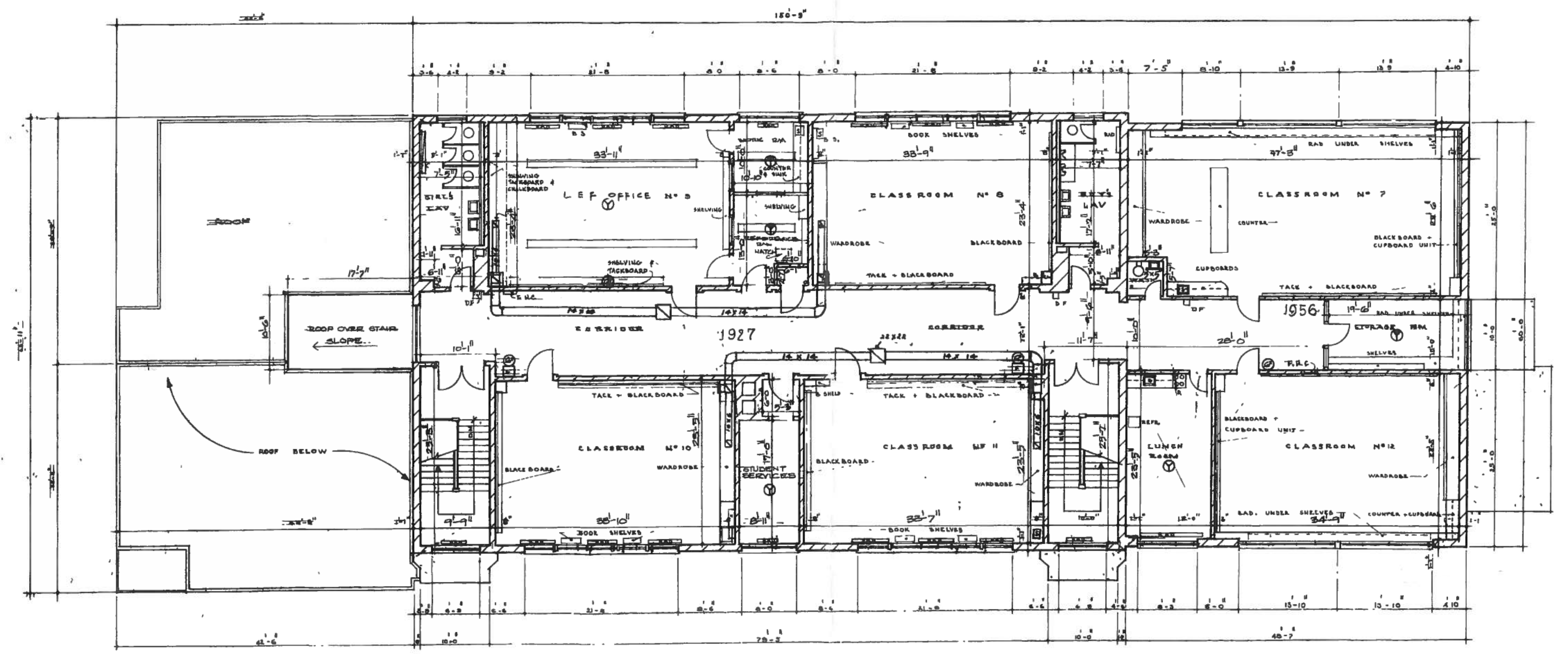

$6110 B 2 A$

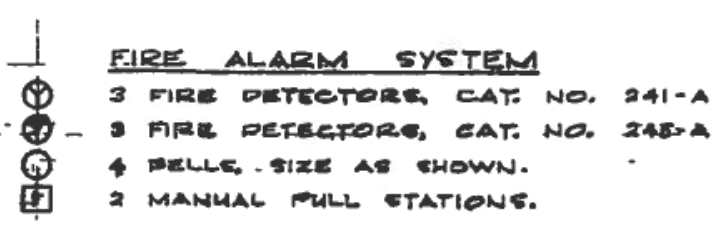

1

$-\cdot-$ -

$\ldots \ldots \ldots$ 


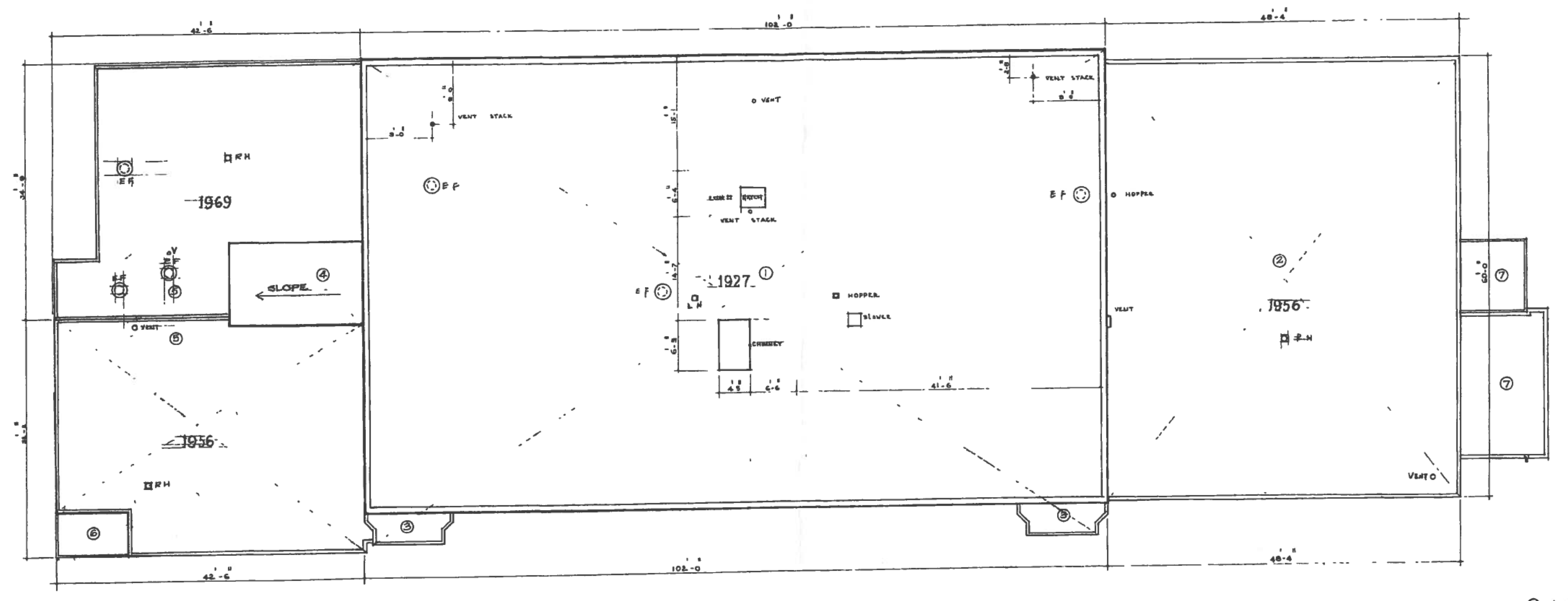

(1) Hather roor level

$-621085$

RoO PLAN

DQAWN Gy AA THE BOARD OF FDUCA

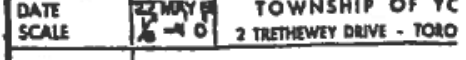

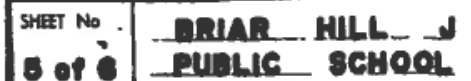

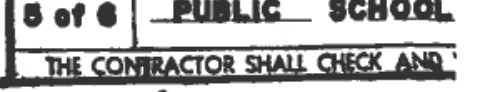




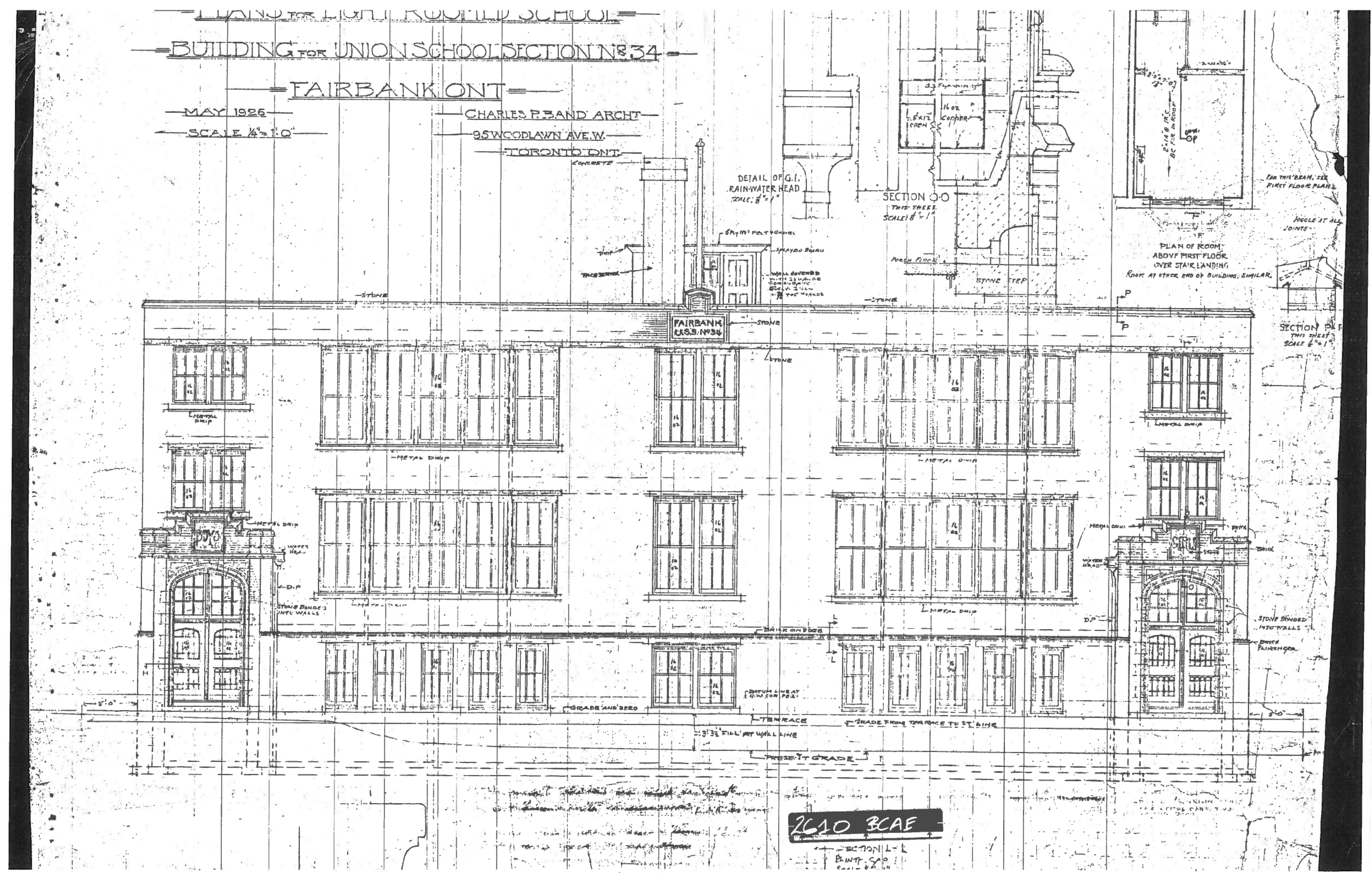




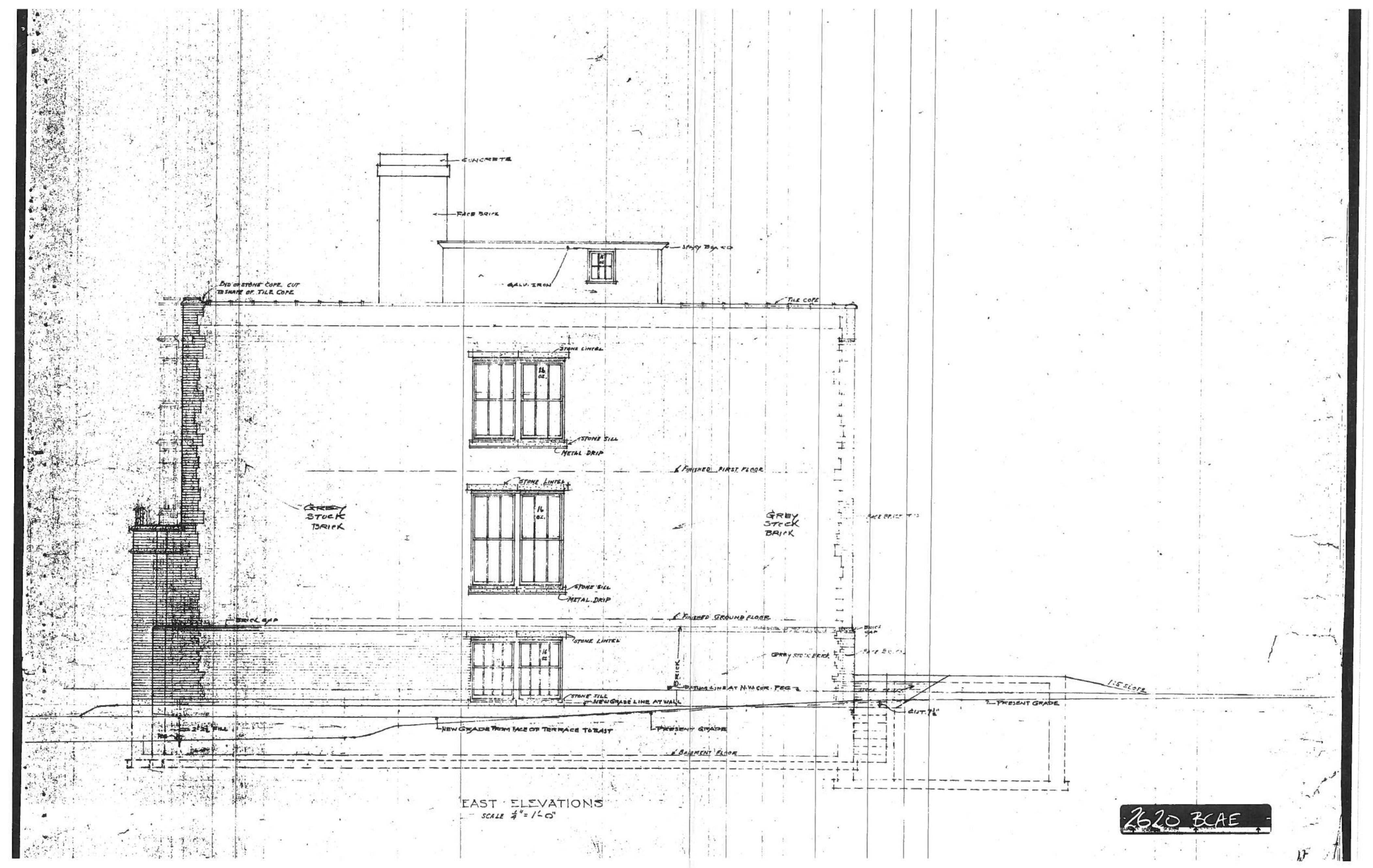




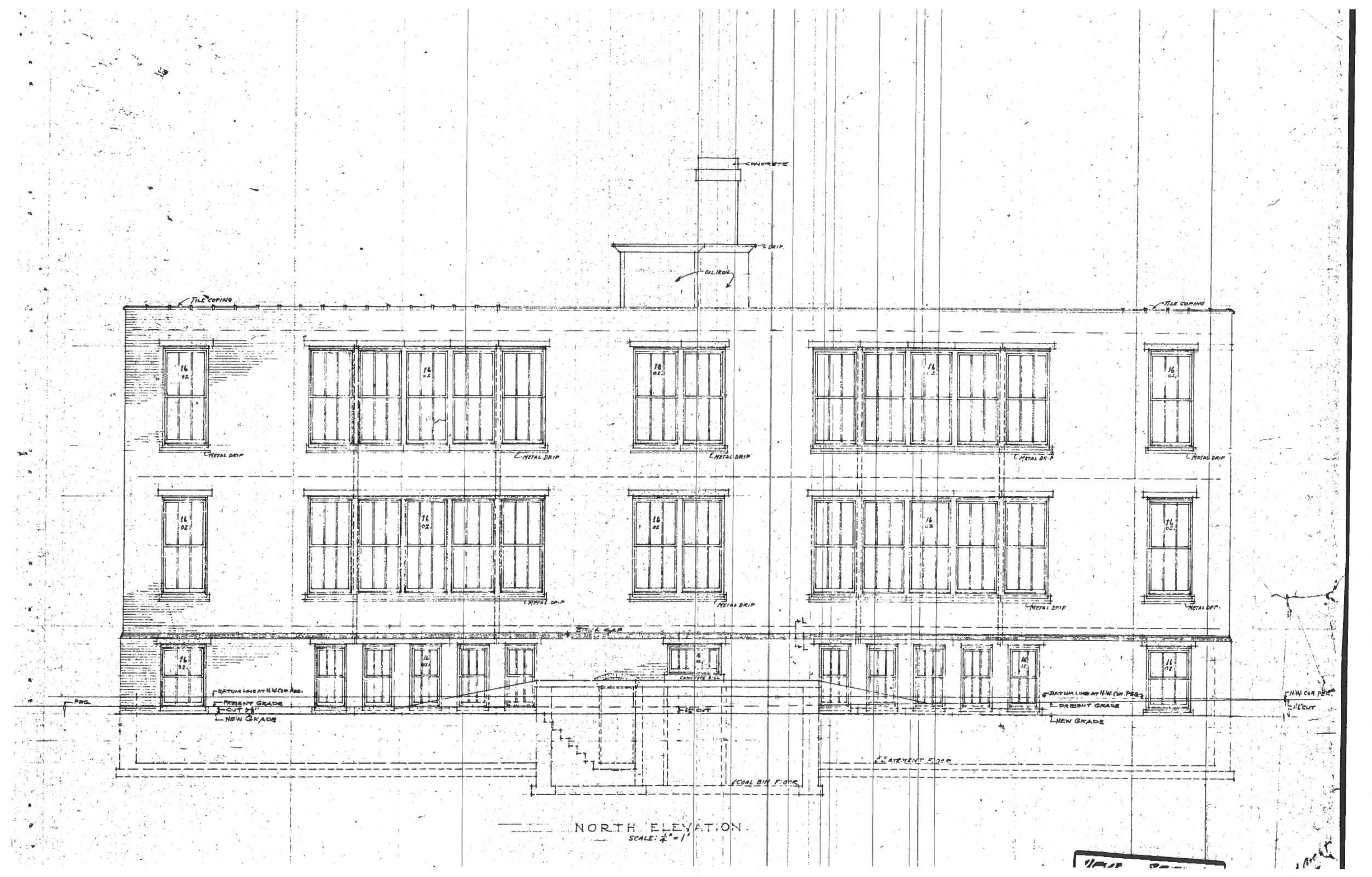


